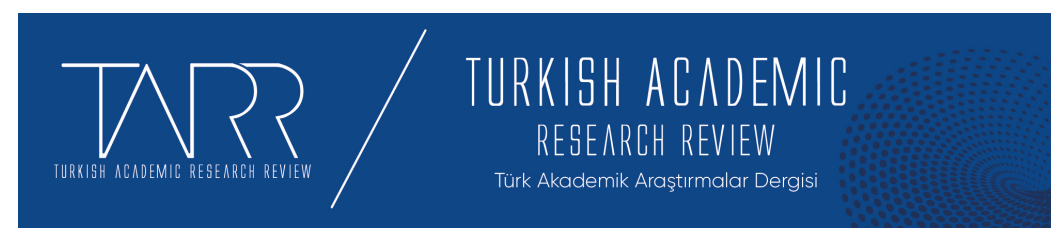

e-ISSN: 2602-2923 Yll/Year: 2021 Cilt/Volume: 6 Sayı/Issue: 5

\title{
Ölçek Geliştirme ve Güvenirlik Analizleri: Jamovi Uygulaması
}

Scale Development and Reliability Analysis: Jamovi Implementation

\section{Kübra KARAKAYA ÖZYER}

Arş. Gör. Dr., Eskişehir Osmangazi Üniversitesi Eğitim Fakültesi, Eğitimde Ölçme ve Değerlendirme Anabilim Dalı/Res. Ass. Dr. Eskişehir Osmangazi University, Faculty of Education, Department of Educational Assessment and Evaluation, kozyer@ogu.edu.tr, Orcid ID: https://orcid.org/0000-0002-0208-7870

\begin{tabular}{r|l} 
Makale Bilgisi & Article Information \\
Makale Türü - Article Type & Araştırma Makalesi / Research Article \\
Geliş Tarihi - Date Received & 4 Ekim / October 2021 \\
Kabul Tarihi - Date Accepted & 28 Aralık / December 2021 \\
Yayın Tarihi - Date Published & 31 Aralık / December 2021 \\
Yayın Sezonu & Aralık \\
Pub Date Season & December
\end{tabular}

Atıf / Cite as: Karakaya Özyer, K., (2021), Ölçek Geliştirme ve Güvenirlik Analizleri: Jamovi Uygulaması/Scale Development and Reliability Analysis: Jamovi Implementation. Turkish Academic Research Review, 6 (5), 1330-1384. Retrieved from https://dergipark.org.tr/tr/pub/tarr/issue/67845/1004560

Intihal / Plagiarism: Bu makale, en az iki hakem tarafından incelenmiş ve intihal içermediği teyit edilmiştir. / This article has been reviewed by at least two referees and confirmed to include no plagiarism. https://dergipark.org.tr/tr/pub/tarr

Copyright (C) Published by Mehmet ŞAHIN Since 2016- Akdeniz University, Faculty of Theology, Antalya, 07058 Turkey. All rights reserved.

Turkish Academic Research Review - Türk Akademik Araştırmalar Dergisi 


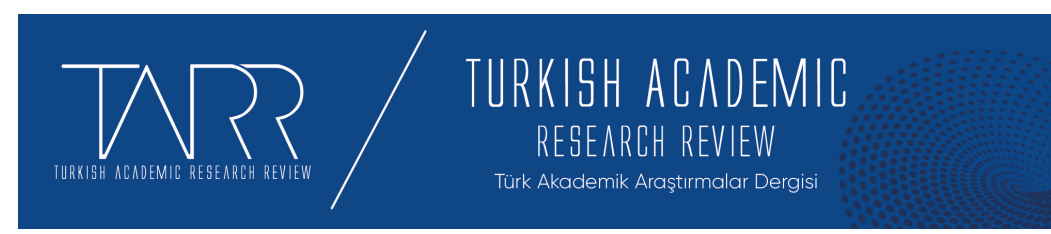

e-ISSN: 2602-2923 Yil/Year: 2021 Cilt/Volume: 6 Sayı/Issue: 5

\title{
Ölçek Geliştirme ve Güvenirlik Analizleri: Jamovi Uygulaması
}

\author{
Kübra KARAKAYA ÖZYER
}

\section{$\ddot{\mathbf{O z}}$}

Sosyal bilimler alanında en çok tercih edilen çalışma türlerinden biri ölçek geliştirmedir. $\mathrm{Bu}$ çalışma türü deneyimsiz ve yetkin olmayan araştırmacılar tarafından yapıldığında ciddi sorunlara yol açabilmektedir. Araştırmacıların istatistiksel analizlerdeki yetersizlikleri ölçek geliştirme sürecinde bir kılavuza ihtiyaç duyduklarını ortaya çıkarmaktadır. Bu çalışma kapsamında, bir ölçek geliştirirken ihtiyaç duyulan tüm istatistiksel analizlerin uygulama adımları anlatılmış ve açık kaynak kodlu ve ücretsiz olan Jamovi programı yardımıyla örneklendirilmiştir. R programlama dili ile geliştirilen Jamovi programı, sosyal bilimler araştırmalarında en çok tercih edilen SPSS programına benzemektedir. Kullanıcı dostu yapısı ve üst düzey analizleri yapabilme kapasitesi ile diğer ücretsiz istatistik programlarından öne çıkmaktadır. Jamovi ile kodlama becerisine gerek duymadan menüler yardımıyla tüm analizler hızlıca yapılabilmektedir. Ayrıca veri penceresi ile çıktı penceresinin aynı anda görüntülemesi ile kullanıcıya oldukça kolaylık sağlamaktadır. Bu çalışmada ölçek geliştirme çalışması için gerekli olan tüm analizler Jamovi programı yardımıyla sunulmuştur. Bu kapsamda verilerin analize hazırlığı, madde analizleri, yapı geçerliliğini ortaya koymak için açıklayıcı ve doğrulayıcı faktör analizleri ve güvenirlik analizleri anlatılmıştır. Verilerin analize hazırlığı bölümünde Jamovi programının temel öğeleri (pencereler, temel menüler, veri aktarımı, değişkenlerin tanımlanması, değişkenlerin dönüştürülmesi vs.) tanıtılmıştır. Diğer bölümlerde ise bahsi geçen tüm analizler örnek veri seti üzerinden gösterilmiştir. Örnek verilerin analiz sonuçlarına dair yorumlara da yer verilmiştir. Elde edilen sonuçların APA formatına göre raporlanmasında dikkat edilmesi gereken noktalar ve sonuçların tablo hali okuyucuya sunulmuştur. Araştırmacılar, bu kılavuz yardımıyla ölçek geliştirme çalışmalarında ihtiyaç duyacakları tüm aşamalara hâkim olabileceklerdir. SPSS programına alternatif olarak ortaya çıkan Jamovi programının Yapısal Eşitlik Modellemesi, Aracılık etkisi, Faktöriyel Varyans Analizi gibi çok değişkenli analizler için de kullanılması önerilmektedir.

Anahtar Kelimeler: Ölçek Geliştirme, İstatistik Programları, Jamovi, Sosyal Bilimler Araştırmaları, Analiz

Turkish Academic Research Review - Türk Akademik Araştırmalar Dergisi 


\title{
Scale Development and Reliability Analysis: Jamovi Implementation
}

\begin{abstract}
Scale development, which is one of the most preferred study types in the field of social sciences. This type of study can cause serious problems when it is done by inexperienced and incompetent researchers. The inadequacies of the researchers in statistical analysis reveal that they need a guide in the scale development process. Within the scope of this study, the application steps of all statistical analyzes needed while developing a scale are explained and exemplified with the help of the open source and free Jamovi program. Developed with the R programming language, the Jamovi program is similar to the SPSS program, which is the most preferred program in social sciences research. It stands out from other free statistical programs with its user-friendly interface and high-level analysis capacity. With Jamovi, all analyzes can be done quickly with the help of menus without the need for coding skills. In addition, it provides a lot of convenience to the user with the simultaneous display of the data window and the output window. In this study, all the analyzes required for the scale development study were presented with the help of the Jamovi program. In this context, the preparation of the data for analysis, item analysis, explanatory and confirmatory factor analyzes to reveal the construct validity and reliability analyzes are explained. In the section of data preparation for analysis, the basic elements of the Jamovi program (windows, basic menus, data transfer, defining variables, transforming variables, etc.) are introduced. In the other sections, all the analyzes mentioned are shown on the sample data set. Comments on the analysis results of the sample data are also included. The points to be considered in reporting the results obtained according to the APA format and the tabular form of the results are presented to the reader. With the help of this guide, researchers will be able to master all the stages they will need in scale development studies. The Jamovi program, which emerged as an alternative to the SPSS program, is also recommended to be used for multivariate analyzes such as Structural Equation Modeling, Mediation Effect, Factorial Variance Analysis.
\end{abstract}

Keywords: Scale Development, Statistics Softwares, Jamovi, Social Science Research, Analysis

\section{Structured Abstract}

Due to the various approaches used in the scale development stages, some researchers and institutions have tried to set the standards for such studies (AERA, APA, and NCME, 1985; DeVellis, 2016). These stages are generally summarized as determining the conceptual framework, creating the item pool, making the pilot application, performing the main application, item analysis, validity and reliability studies. Although the mentioned scale development stages are clear, the process does not progress linearly when it is put into practice. Literature review and expert opinion can be consulted at every stage of scale development and, if necessary, the previous step can be returned to. For these reasons, the researcher needs to have both knowledge of the field and the details of the scale development process for the scale development study (Erkuş, 2007).

The Jamovi program was developed in 2017 as an open source code (open to be developed by every researcher in the world) based on the $\mathrm{R}$ programming

Turkish Academic Research Review - Türk Akademik Araştırmalar Dergisi 
language. It can be downloaded to computers free of charge from https://www.jamovi.org/download.html. A researcher who has mastered the $\mathrm{R}$ programming language has the right to develop and modify the Jamovi codes. Its use is similar to the SPSS package program.

SPSS and AMOS programs (or LISREL), which are most frequently used in scale development studies, have some disadvantages. These disadvantages are the cost of access to the software, the need for separate programs for explanatory and confirmatory factor analysis (SPSS for AFA, AMOS or LISREL for DFA). However, Jamovi offers users the opportunity to perform both explanatory factor analysis and confirmatory factor analysis in a single program. Guidance service was provided to researchers by using Jamovi, which is provided free of charge, in the sample scale development study.

In this study, the applicability of analyzes is demonstrated with the Jamovi program in order to enable researchers who have just started scale development studies to understand the necessary statistical issues more easily.

\section{Scale Development Analyses}

\section{Data Preparation}

Before getting start to analyses in Jamovi, the data must be ready for analysis. The Jamovi program consists of three basic windows: 1-data window on the left of the screen where data is manually entered or transferred (import), 2analysis window that appears on the screen after the analysis is selected and details about the analysis are presented, 3-output window where analysis results and necessary tables appear.

First of all, it should be checked whether there are adverse items in the instrument prepared to develop the scale. If there is an item in the scale that contradicts other items or has a negative expression, this item or items should be determined; Afterwards, these items should be reverse-coded.

One of the important steps of the scale development phase is the item analysis. Some analyzes and coefficients are used to decide which items will be removed and which will remain in the scale. First, the correlation between the items should be revealed by calculating the correlation matrix.

By default in Jamovi, Pearson is checked under the Correlation Coefficients section. However, this coefficient is recommended to be used in cases where the data are normally distributed. Spearman coefficient can be preferred for items that do not show normal distribution (Field, 2009).

Inter-item correlation values are expected to be between 0.20 and 0.90 . Items with a low correlation coefficient do not act together with other items and do not represent the concept to be measured. On the other hand, items with a high correlation coefficient (.90 and above) are perceived as overlapping or the same items measuring the same concept. In both cases, the items should be removed from the item pool as they damage the structure of the scale.

After examining the correlation matrix, item-remainder or item-total correlations can be looked at for item analysis. The Item Reliability Statistics table in the output window shows the item-rest and if item dropped values for each item. The user can select the values they want to be included in the table from the Scale Statistics and Item Statistics sections. 


\section{Construct Validity: Explanatory Factor Analysis}

Another type of analysis in which item analysis can be done in scale development studies is Explanatory Factor Analysis (EFA). Researchers who develop a scale for a concept have to use explanatory factor analysis (Erkuş, 2012). To perform Explanatory Factor analysis in Jamovi, the Factor section in the Analyzes tab should be used.

In order to determine whether the data show a multivariate normal distribution, Bartlett's test of sphericity in the Assumption Checks section, which is the assumptions section, should be checked. The Bartlett test helps to reveal whether the correlations between the scale items are suitable for factorization (Karasar, 2010). The significance level (p) of the Bartlett test is expected to be less than 0.05 (Alpar, 2013; Güriş \& Astar, 2015). However, since this test is affected by the sample size, it is likely to be significant in analyzes with large samples (Tabachnick \& Fidell, 2015). In addition, the Kaiser-Meyer-Olkin (KMO) measure of sampling adequecy value should be checked to determine the adequacy of the data collected for scale development. The KMO value can take a value between 0 and 1 , and values close to 1 indicate that the sample is suitable for factor analysis (Alpar, 2013; Field, 2009).

After the assumption checks, the user factor extraction methods should be decided. The Jamovi program offers users three methods of factor subtraction: minimum residuals (smallest errors), maximum likelihood (maximum likelihood) and principal axis methods (See Figure 28). Each method has its own advantages and disadvantages. The principle axis method is the second most preferred method in the literature (Tabachnick ve Fidell, 2015; Thompson, 2008). It is recommended to be preferred in cases where the reliability values of the results of the scale are high and the items do not show normal distribution (Fabrigar, Wegener, MacCallum, \& Strahan, 1999; Thompson, 2008). The maximum likelihood method, on the other hand, is known as one of the methods that gives the best results when the assumptions of the factor analysis are met (the data show normal distribution) (Huck, 2012). The method that is most suitable for the structure of the data and the purpose of the research should be preferred and the stage of giving until the factor rotation method should be started.

While Jamovi presented the varimax and quartimax methods for vertical rotation as factor rotation methods, it highlighted promax, oblimin (direct oblimin) and simplimax methods from oblique rotation methods.

At this point, the researcher should be careful and give the number of factors by considering the theoretical framework and different factor extraction criteria. There are various criteria for giving the number of factors: Kaiser criterion (Kaiser, 1960, Slope plot (Cattell, 1966), percentage of variance criterion, Minimum Means Test (Velicer, 1976) and parallel analysis (Horn, 1965).

When it comes to deciding on the number of factors, Jamovi offers the Parallel Analysis method by default (See Figure 30). However, the number of factors can also be determined according to the eigenvalue and fixed number methods. In addition, the number of factors can be decided with the help of the Scree plot under the Additional output section.

In the current study, the factor loadings of the items are shown in the Factor Loadings table. The Uniqueness values in the last column of this table indicate the change in the item independent of the factors. The values in this column are expected to be low.

Turkish Academic Research Review - Türk Akademik Araştırmalar Dergisi 


\section{Construct Validity: Confirmatory Factor analysis}

After the structural model is determined in scale development studies, the structure needs to be verified. Confirmatory Factor analysis is used to reveal how well the factors created through explanatory factor analysis and their relations with the items reflect the theoretical framework (Özdamar, 2013).

There are various methods for calculating the estimated values of model parameters in confirmatory factor analysis. The most commonly used estimation method is the Maximum Likelihood method. Jamovi calculates parameter coefficients using the Maximum likelihood method. However, it is not possible to use different methods yet.

Jamovi automatically presents the Chi-square test, CFI, TLI and RMSEA values, which are the most reported model fit indices in the literature, to the user.

When the default model is not fully compatible or the model is desired to be developed, the Modification indices section in the Additional Output tab can be checked.

Finally, when the Path Diagram on the Additional Output tab is checked, the graph of the model defined by the Confirmatory Factor analysis will take its place in the output window (See Figure 43). It is recommended to include path graphs in research and to embody the item-factor relations.

\section{Reliability Analysis}

After the construct validity of the results obtained from the scale has been proven, the reliability coefficients should be presented to the reader. In order to calculate the reliability coefficients in the Jamovi program, the Reliability Analysis option under the Factor section in the Analyzes tab should be selected. When the Correlation heatmap tab in the Additional output tab is checked, a figure showing the relationship of the items with each other appears. Thus, the analysis of the items can also be done at this stage.

\section{Giriş}

Ölçek geliştirme aşamalarında kullanılan çeşitli yaklaşımlar sebebiyle bazı araştırmacılar ve kurumlar bu tür çalışmaların standartlarını belirlemeye çalışmışlardır (AERA, APA ve NCME, 1985; DeVellis, 2016). Bu aşamalar genellikle kavramsal çerçevenin belirlenmesi, madde havuzunun oluşturulması, pilot uygulamanın yapılması, esas uygulamanın yapılması, madde analizleri, geçerlilik ve güvenirlik çalışmaları olarak özetlenmiştir. Bahsi geçen ölçek geliştirme aşamaları belli olsa da uygulamaya geçildiğinde süreç doğrusal bir biçimde ilerlememektedir. Ölçek geliştirmenin her aşamasında literatür taraması ve uzman görüşüne başvurulabilir ve gerekirse bir önceki adıma tekrar dönülebilmektedir. Bu sebeplerden ötürü ölçek geliştirme çalışması için araştırmacının hem alana hâkim olması hem de ölçek geliştirme sürecindeki detayları bilmesi gerekmektedir (Erkuş, 2007). 
Uzun ve engebeli bir yol olan ölçek geliştirme sürecinde en çok zorlanılan konulardan biri de analizlerin istatistik yazılımları aracılığıyla yapılmasıdır. Akademik çalışmalarda, bu analizler için pek çok yazılım bulunmaktadır ancak bunlardan en popüler olanları SPSS, LISREL ve AMOS'tur (Muenchen, 2019). Türkiye'de eğitim araştırmalarında en çok kullanılan üç istatistiksel yazılımın SPSS, LISREL ve AMOS olduğunu ortaya konulmuştur (Yazar, 2021). Ancak son yıllarda bu yazılımların ücretli olması ve kullanıcı dostu olmaması sebebiyle alternatif yazılımlar tercih edilmeye başlanmıştır (Örnek: JASP, Jamovi).

Jamovi programı açık kaynak kodlu (dünyadaki her araştırmacı tarafından geliştirilmeye açık olan) R programlama dil tabanlı ve grafiksel gösterimli olarak 2017 y1lında geliştirilmiştir. https://www.jamovi.org/download.html adresinden ücretsiz olarak bilgisayarlara indirilebilmektedir. R programlama diline hakim olan bir araştırmacı Jamovi kodlarını geliştirme ve değiştirme hakkına sahiptir. Kullanımı SPSS paket programına benzemektedir. Erişiminin ücretsiz olması ve ek modüller yardımıyla geniş analiz yelpazesine sahip olması sebebiyle Jamovi son yıllarda sosyal bilimler alanında sıklıkla kullanılmaya başlanmıştır. Jamovi "araştırmacı ile istatistikçi arasında bir köprü görevi gören ücretsiz ve açık yazılım” mottosuyla kurulduğu günden bugüne kendini geliştirmeye devam etmektedir.

Betimsel istatistikler, t-testleri, ANOVA, korelasyon ve regresyon, frekans analizi, parametrik olmayan testler, açılayıcı ve doğrulayıcı faktör analizleri Jamovi programının temel analizleridir. Bunların dışında Modüller (Modules) bölümü kullanılarak aracılık etkisi, Path analizi ve meta-analiz gibi farklı analizlerin programa eklenmesi sağlanabilmektedir. Araştırmacılar sık kullandıkları modülleri ekranda ister görünür kılarak isterse de gizleyerek kullanıcı-dostu bir deneyim elde edebilmektedir.

Ölçek geliştirme çalışmalarında en sık kullanılan SPSS ve AMOS programlarının (veya LISREL) bazı dezavantajları bulunmaktadır. Bu dezavantajlar, yazılımlara erişimin ücretli olması, açıklayıcı ve doğrulayıcı faktör analizleri için ayrı ayrı programlara ihtiyaç duyulmasıdır (AFA için SPSS, DFA için AMOS veya LISREL). Ancak Jamovi kullanıcılara tek bir programda hem açıklayıcı faktör analizi hem de doğrulayıcı faktör analizi yapma imkânı sunmaktadır. Örnek ölçek geliştirme çalışmasında ücretsiz erişim sağlanan Jamovi kullanılarak araştırmacılara rehberlik hizmeti sunulmuştur.

Turkish Academic Research Review - Türk Akademik Araştırmalar Dergisi https://dergipark.org.tr/tr/pub/tarr 
$\mathrm{Bu}$ çalışmada temel olarak ölçek geliştirme çalışmalarına yeni başlayan araştırmacılara gerekli istatistik konularını daha kolay kavramalarını sağlamak amacıyla Jamovi programı ile analizlerin uygulanabilirliği gösterilmektedir.

\section{Jamovi Uygulaması}

\subsection{Verilerin Analize Hazırlanması}

Jamovi'de uygulamaya geçmeden önce verinin analize hazır hale getirilmesi gerekmektedir.

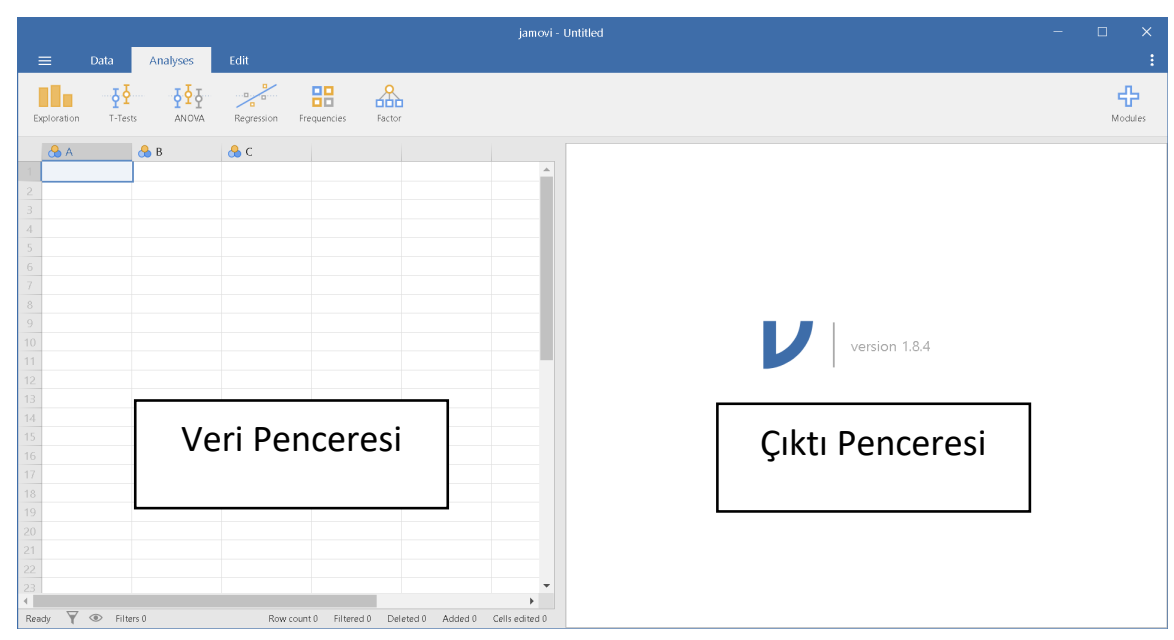

\section{Şekil 1. Jamovi 1.8.4 Ara Yüzü}

Bilgisayara başarıyla kurulan programın ikonuna tıklandığında kullanıcıyı karşılayan ekran Şekil 1'deki gibidir. Jamovi programı üç temel pencereden oluşmaktadır:1-verilerin elle girildiği veya aktarıldığı (import) ekranın solunda bulunan veri penceresi, 2-analizlerin seçiminden sonra ekranda beliren ve analize dair ayrıntıların sunulduğu analiz penceresi,3-analiz sonuçlarının ve gerekli tabloların belirdiği çıktı penceresi.

Boş Jamovi belgesindeki veri penceresine elle veri girişi yapılabilmektedir. Ancak istenirse xlsx, csv, txt, sav (SPSS), dta (STATA), xpt (SAS), ve jasp uzantılı dosyaların import seçeneği kullanılarak programa aktarılması sağlanabilmektedir. Diğer bir ifade ile Excel veya SPSS'de hazırlanmış olan veri dosyaları Jamovi programında kolaylıkla kullanılabilmektedir. 


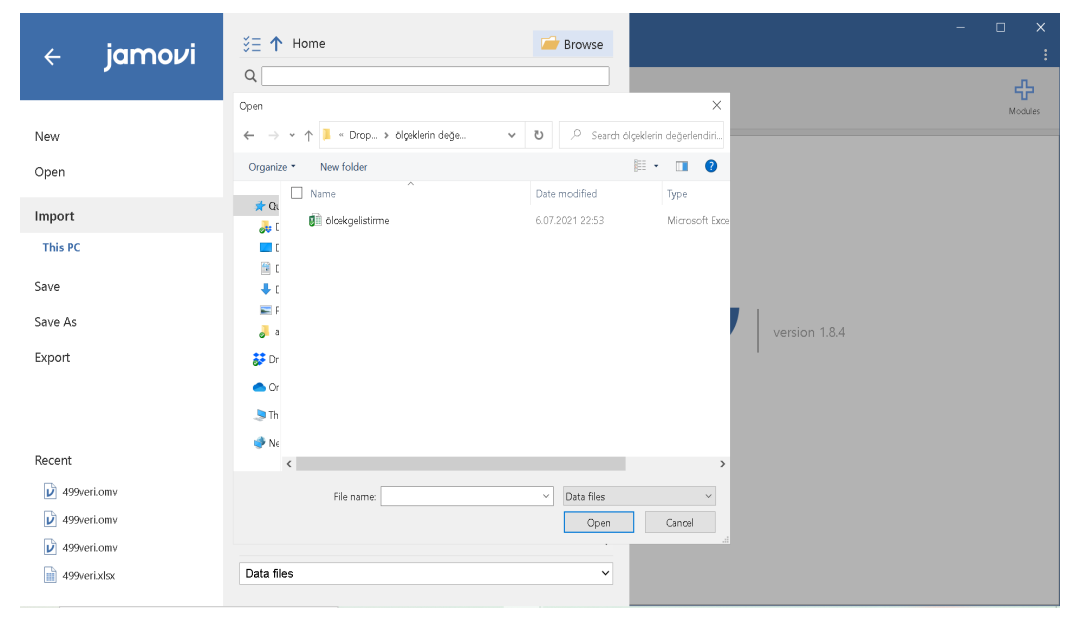

\section{Şekil 2. Jamovi Programına Veri Aktarma}

Ölçek maddelerinin girilmiş olduğu veri dosyası (cvs, txt veya sav) Jamovi programına örnekteki gibi aktarılır (Bknz Şekil 2). Aktarım tamamlandıktan sonra Save (Kaydet) butonu yardımıyla Jamovi dosyası bilgisayara kaydedilir.

Uyarı: Programın yeni sürümlerinde ani kapanmalar yaşanabildiğinden dolayı kullanırken sık sık dosyanın kaydedilmesi tavsiye edilir.

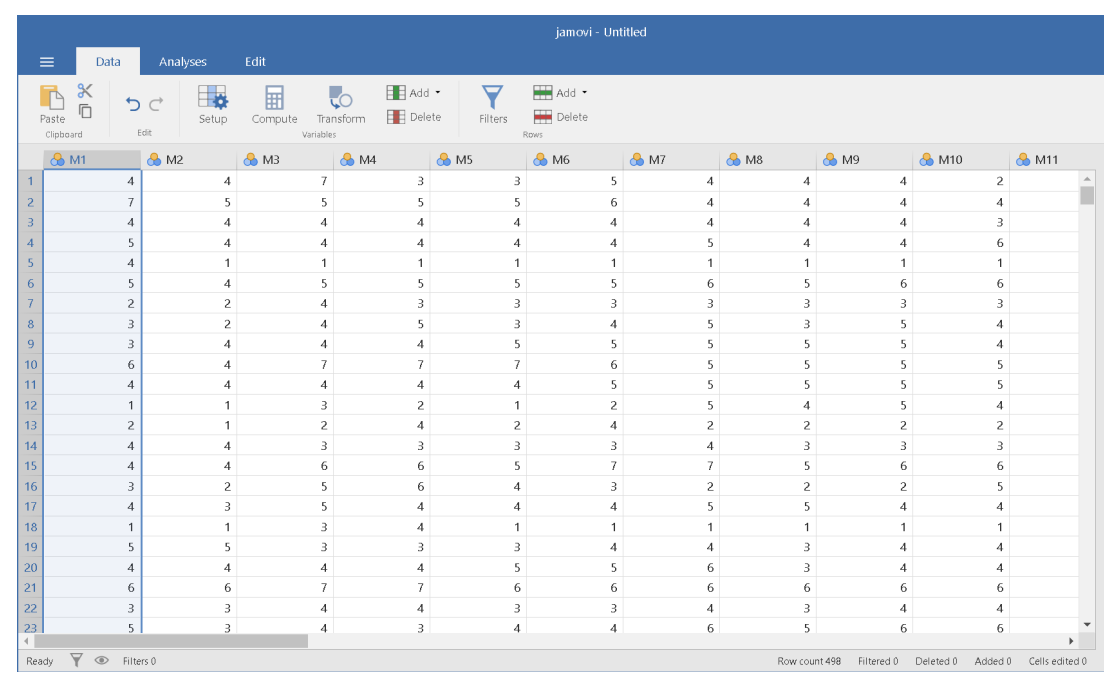

\section{Şekil 3. Ölçek Geliştirme Veri Penceresi}

Veriler yüklendikten sonra değişkenlerin ölçekleme biçimleri değiştirilebilmektedir. Jamovi programı, Likert tipindeki ölçek maddelerini 
sınıflayıcı (Nominal) olarak algıladığı için değişkenlerin ölçeklendirme biçimlerinin eşit aralıklı olarak düzenlenmesi gerekmektedir (Şekil 3). Bu değişikliği yapabilmek için madde (değişken) işaretlenmelidir. Bu esnada değişkenin özellikleri ekranda belirmektedir (bknz Şekil 4).

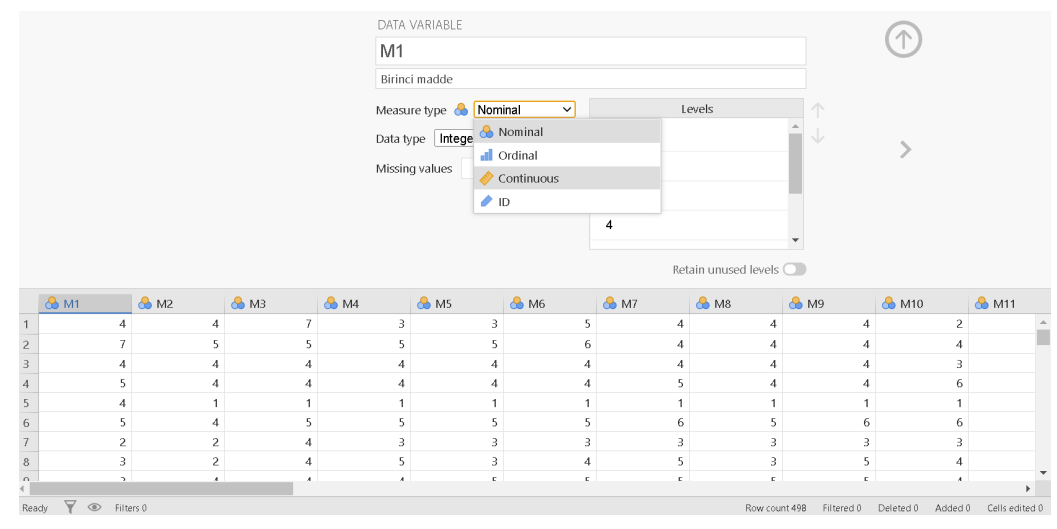

\section{Şekil 4. Değişken Özelliklerini Değiştirme}

Data Variable bölümünde; değişkenin adını değiştirme, değişkenin açıklamasını yazma, ölçekleme yöntemini düzenleme (measure type) ve kayıp verileri (missing values) tanımlama işlemleri yapılabilmektedir. Levels bölümünde maddede bulunan seviyeler gösterilmektedir. Ölçek maddelerinin sürekli değişken olarak tanımlanması istendiği için 'sürekli (continuous) bölümü’ tercih edilmiştir. Tüm maddelerde gerekli değişiklikler yapıldıktan sonra verilerin kontrol aşamasına geçilir.

İlk olarak ölçek geliştirmek için hazırlanan maddelerde ters maddelerin olup olmadığı kontrol edilmelidir. Eğer ölçekte diğer maddeler ile ters düşen veya olumsuz bir ifade barındıran madde var ise bu madde veya maddeler belirlenmeli; sonrasından ise bu maddelere ters kodlama işlemi yapılmalıdır. Örnekteki ölçekte 19. ve 21. maddeler ters madde olarak tespit edilmiştir.

Ters kodlama için maddenin üzerine gelinip madde seçilmelidir. Ardından Data bölümündeki transform sekmesi tıklanmalıdır. $\mathrm{Bu}$ sekme tıklandığı anda Jamovi maddenin bir kopyasını oluşturup onun üzerinde değişim yapma imkânı sunmaktadır. 


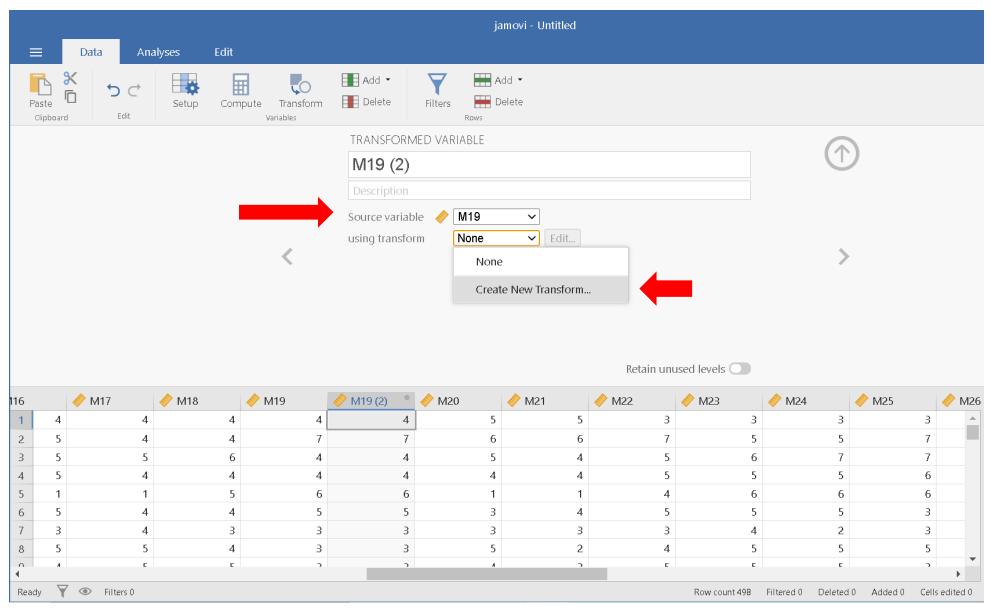

\section{Şekil 5. Olumsuz Maddelerin Ters Kodlanması}

Şekil 5'teki gibi açılan pencereden using transform sekmesi tercih edilmelidir. Create new transform ile yeni bir dönüştürme (transform) tanımlanabilir.

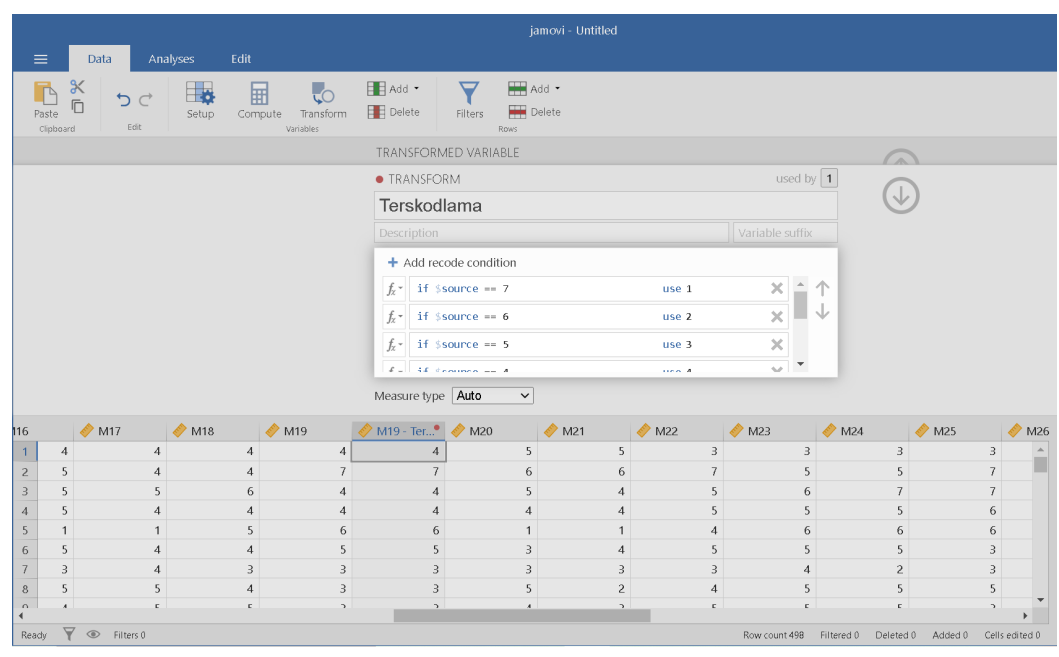

\section{Şekil 6. Ters kodlama için fonksiyon tanımlama}

Ters kodlama dönüşümü için "Add recode condition" butonu tıklanarak dönüşüm yapılmak istenen ölçek noktaları yazılır. Örnekte 7'li Likert tipinde bir ölçekleme yöntemi kullanıldığı için her 7 olan veriyi 1 olacak biçimde ters kodlama durumu tanımlanır (Bknz Şekil 6). Benzer şekilde diğer ölçek noktaları da dönüşüm fonksiyonu tanımlanır. $\mathrm{Bu}$ aşamada tüm ölçekleme noktalarının ters kodlama puanlarının tanımlanmış olmasına dikkat edilmelidir. Tüm ters kodlama 
tanımlamaları yapıldıktan sonra bu dönüşüme bir ad verilebilir. Örnekte Terskodlama adı verilmiştir. Bu aşamada aşağı ok tuşuna basıldığında maddenin özelliklerinin göründüğü ekran ortaya çıkmaktadır.

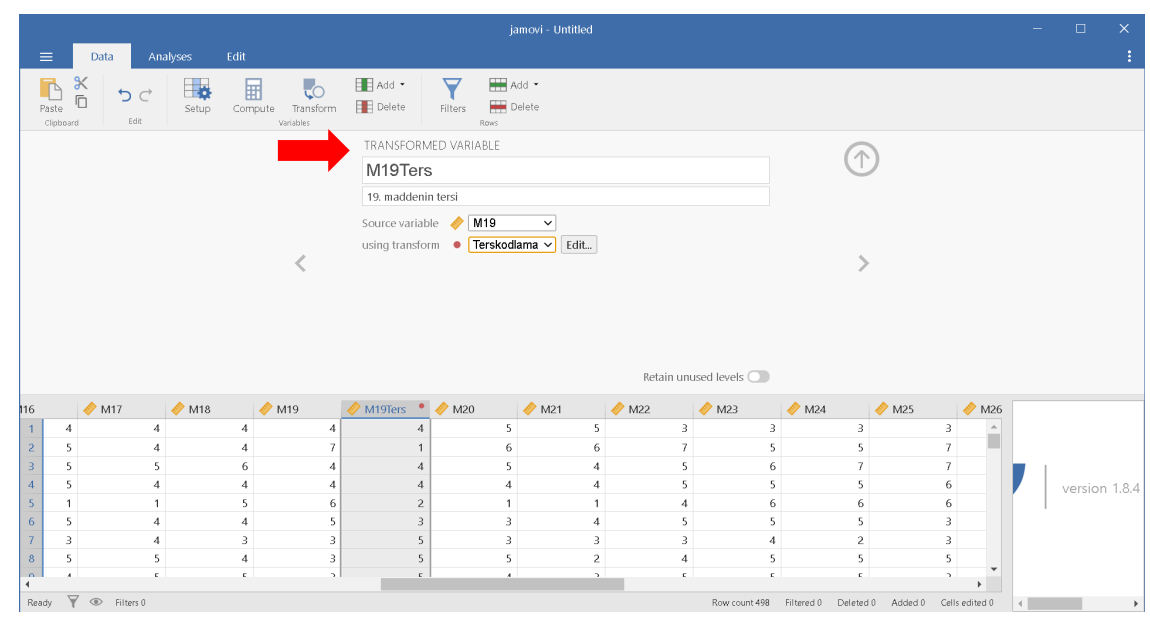

\section{Şekil 7. Ters kodlanmış değișkene isim verme}

Maddenin dönüşümü tamamlandığında, 19. maddenin ters kodlama dönüşümü yapılmış hali M19Ters olarak veri setinde yerini almıştır (Bknz Şekil 7). Aynı işlem 21. madde için de gerçekleştirilmesi gerekmektedir. 21. maddenin dönüşümü yapılırken using transform bölümündeki Terskodlama dönüşüm fonksiyonu kolaylıkla kullanılabilir. Ters kodlama işlemleri bittikten sonra verilerin incelenmesi aşamasına geçilmelidir.

Verilerin ilk incelemesinin yapılabilmesi için betimsel istatistiklerden yararlanılabilir.

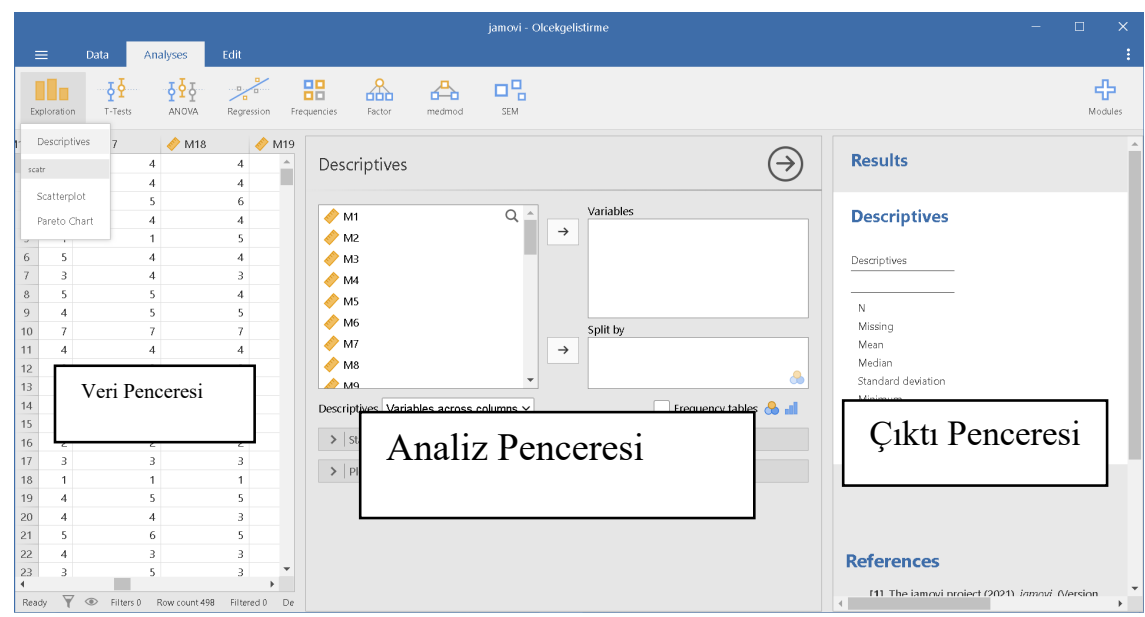

Turkish Academic Research Review - Türk Akademik Araştırmalar Dergisi https://dergipark.org.tr/tr/pub/tarr 


\section{Şekil 8. Betimsel İstatistikler Menüsü}

Analyses (Analiz) sekmesinin Exploration (Keşfetme) bölümüne tıklandığında Descriptives (Betimsel istatistikler) bölümü belirmektedir (Bknz Şekil 8). Descriptives tıklandığında Analiz penceresi ve Output (Çıktı) penceresi tek bir ekranda belirmektedir. Jamovi uygulamasının en önemli avantajlarından biri analiz ve çıktı pencerelerinin yan yana bulunmasıdır. $\mathrm{Bu}$ sayede kullanıcı pencereler arasında hızlı geçişler yaparak analiz sonuçlarında değişiklikler yapabilmektedir. $\mathrm{Bu}$ aşamada tüm maddeler incelenmek istendiği için Analiz penceresinde bulunan tüm maddeler variables (değişkenler) kutusuna aktarılır.

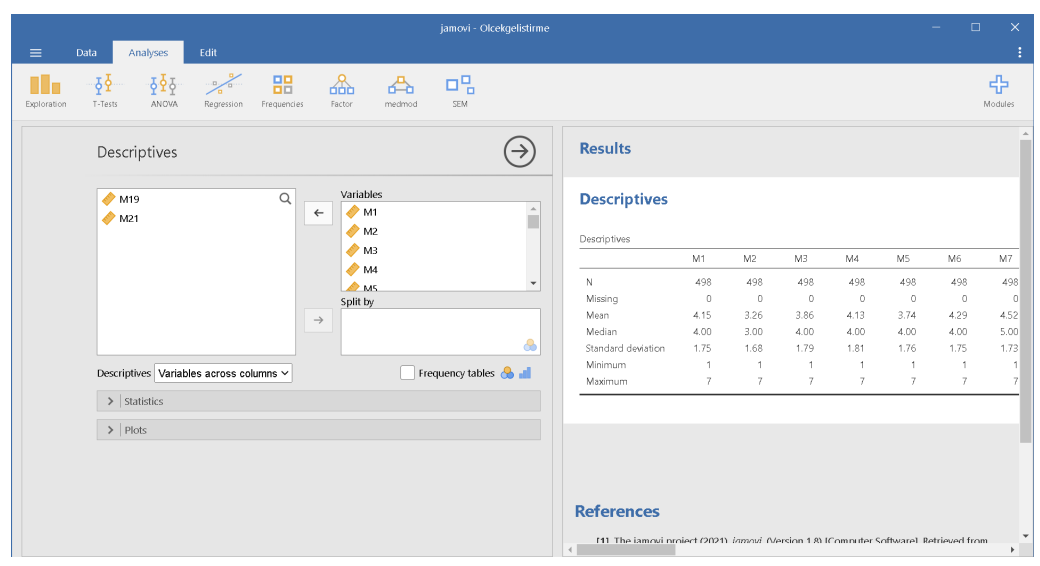

Şekil 9. Betimsel İstatistikler Analiz ve Çıktı Pencereleri

Değişken kutusuna maddeler atıldığı anda Jamovi analizlere başlar ve varsayılan olarak sabitlenmiş olan örneklem sayısı (N), kayıp veri sayısı (Missing), ortalama (Mean), Ortanca (Median), standart sapma (Standard deviation), minimum ve maksimum değerleri hesaplanır (Bknz Şekil 9). Kullanıcı Statistics sekmesine tıklayarak betimsel istatistikler kısmını özelleştirebilir. Varyans (variance), ranj (range), orta değer (Mode), toplam (sum), çeyrek değerler açıklığı (interquartile range), ortalamaların standart hatası (Std. Error of Mean) ve ortalamanın güven aralığ (betimsel istatistikler) tablosuna eklenebilmektedir.

Turkish Academic Research Review - Türk Akademik Araştırmalar Dergisi https://dergipark.org.tr/tr/pub/tarr 


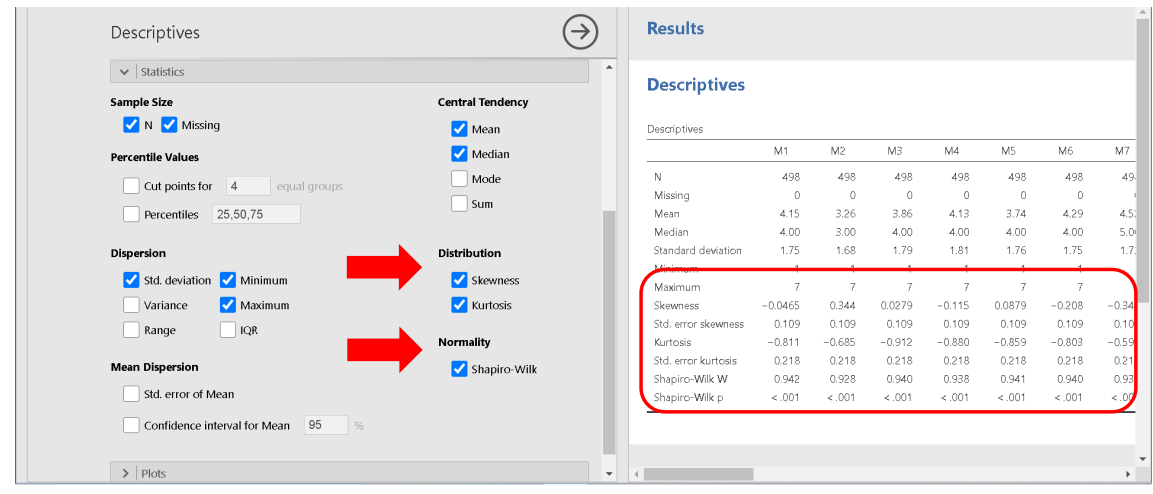

Şekil 10. Betimsel İstatistikler Analiz Penceresi İlave Değerler

Şekil 10'da görüldügüü üzere Statistics sekmesi altında bulunan skewness (çarpıklık) ve kurtosis (basıklık) değerleri maddelerin normal dağılım gösterip göstermediği konusunda yardımcı olabilmektedir. Bu değerler dışında Normality bölümündeki Shapiro-Wilk testine tıklanarak her maddeye ait normallik test sonuçlarına anında ulaşılabilmektedir.

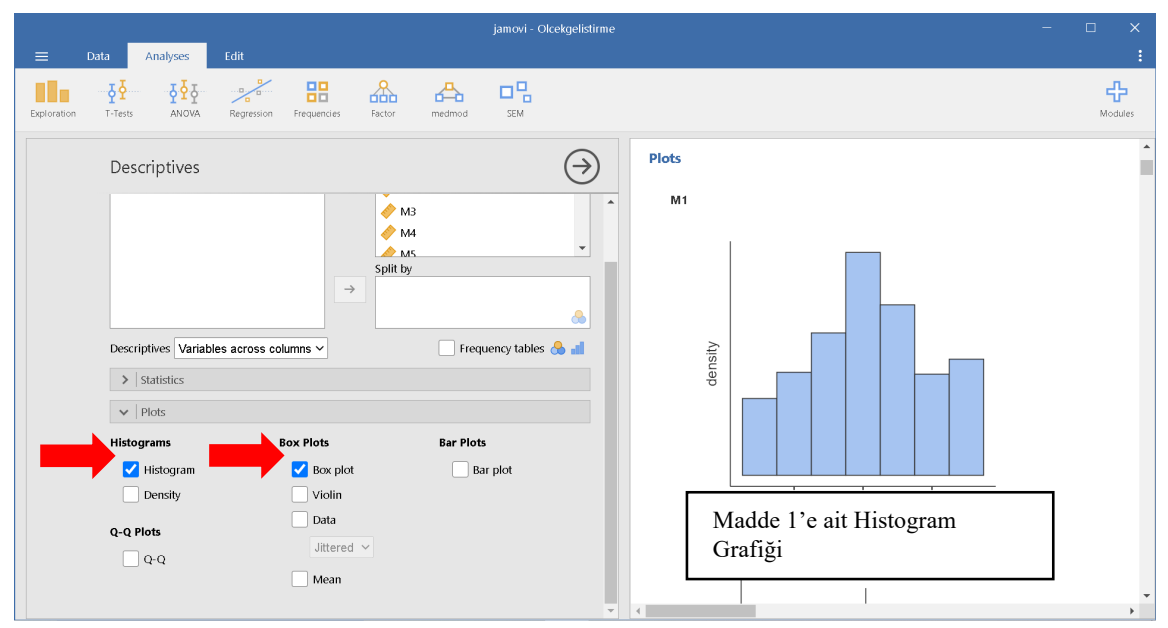

\section{Şekil 11. Betimsel İstatistikler Histogram ve Kutu Grafiği Çizme}

Plots bölümündeki Histogram ve Box plot (Kutu grafiği) seçenekleri de verilerin normalliği konusunda ipuçları verebilmektedir (Bknz Şekil 11).

Shapiro Wilk testi sonuçlarının anlamlllık düzeyi .05 'ten büyük olması verilerin normal dağılım gösterdiğini ifade etmektedir. Ek olarak, ortalama ve 
ortanca değerlerin birbirilerine yakın olması da verilerin normalliğe yakın olduğunu göstermektedir (Güriş ve Astar, 2015). Çarpıklık ve basıklık değerlerinin -1 ile +1 arasında kalması da normallik için kanıt olarak gösterilebilmektedir (Field, 2009). Son olarak, Histogram, Q-Q plot ve box plot grafikleri incelenerek normal dağılım denetlenebilmektedir. Normal dağılım gösteren verilerin Histogram grafikleri çan eğrisine benzemektedir. Görsel olarak çan eğrisine benzeyen değişkenlerin normal dağılıma yakın dağılım gösterdiği söylenebilir. Maddelere ait verilerin istatistikleri ve histogram grafikleri incelenmesi sonucunda verilerde herhangi bir anormallik tespit edilmemiş̧ir.

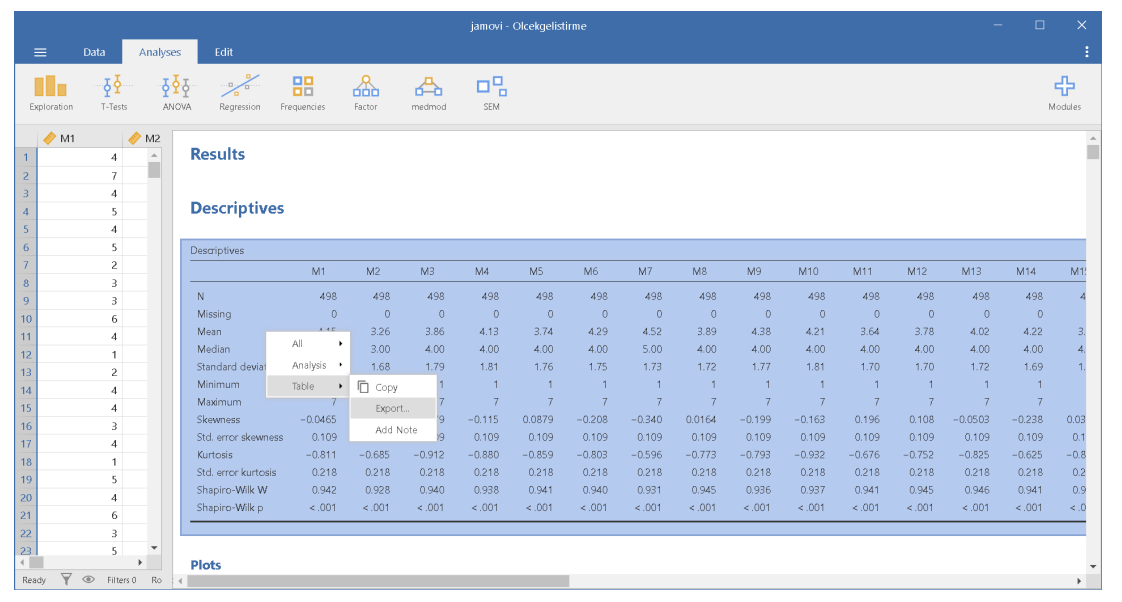

Şekil 12. Çıktı Penceresindeki Tabloların Dışa Aktarımı

Jamovi’nin çıktı penceresindeki tablolar ve grafikler seçildiğinde sağ tuşa tıklanarak Export bölümünden pdf olarak kaydedilebilmektedir.

\section{2. Ölçek Maddelerinin Analizleri}

Ölçek geliştirme aşamasının önemli adımlarından biri de madde analizlerinin yapılmasıdır. Hangi maddelerin çıkartılıp hangilerinin ölçekte kalacağına karar verebilmek için bazı analizlerden ve katsayılardan yararlanılmaktadır.

İlk olarak, maddeler arası korelasyon matrisi hesaplanarak maddelerin birbiriyle ilişkileri ortaya konulmalıdır.

Turkish Academic Research Review - Türk Akademik Araştırmalar Dergisi https://dergipark.org.tr/tr/pub/tarr 


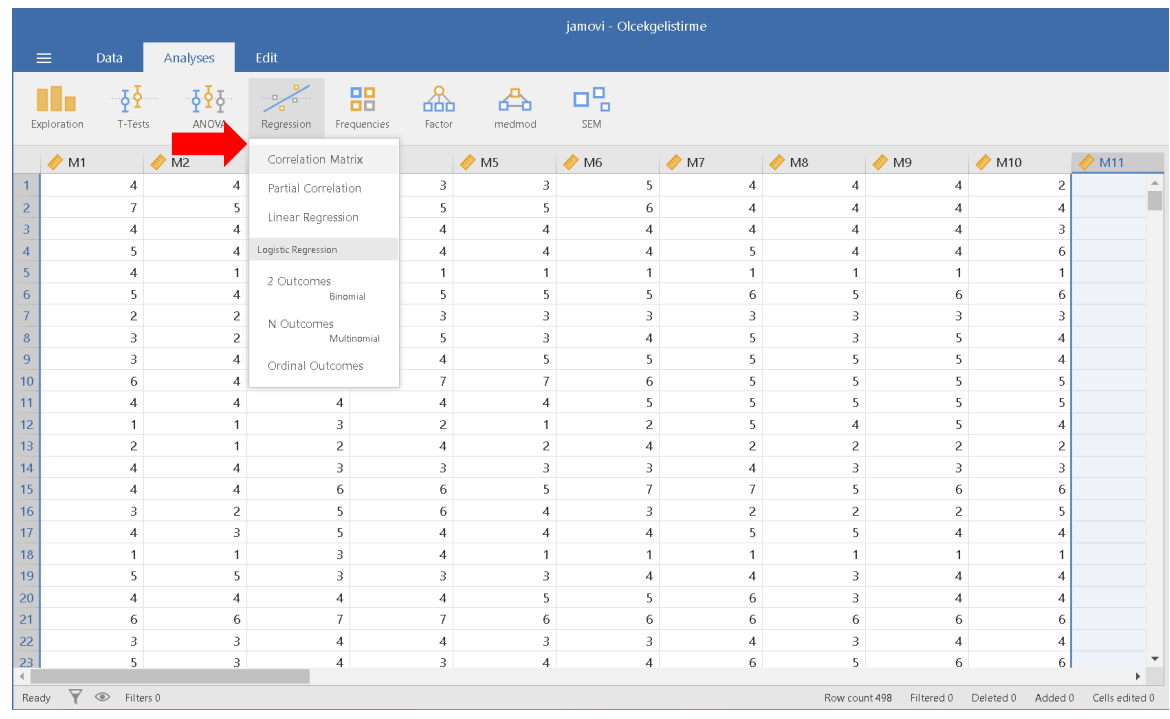

Şekil 13. Analiz Sekmesi Regresyon Menüsü

Jamovi'de korelasyon matrisinin hesaplanabilmesi için Analyses sekmesinin Regression bölmesindeki Correlation matrix kısmının tıklanması gerekmektedir (Bknz Şekil 13).

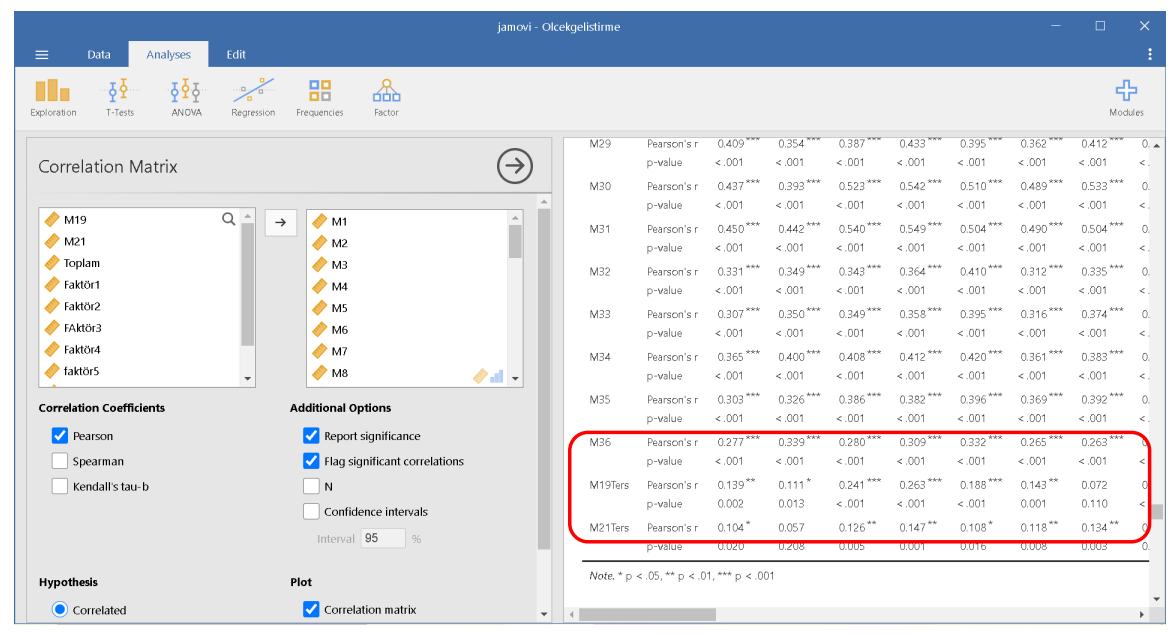

\section{Şekil 14. Korelasyon Matrisi Hesaplama}

Korelasyon matrisini oluşturmak için öncelikle korelasyon hesaplama yöntemine karar verilmelidir. Jamovi’de varsayılan olarak Correlation Coefficients (Korelasyon katsayıları) bölümünün altında bulunan Pearson işaretlidir. Ancak bu 
katsayı verilerin normal dağılım gösterdiği durumlarda kullanılması tavsiye edilir. Normal dağılım göstermeyen maddeler için ise Spearman katsayısı tercih edilebilir (Field, 2009). Flag significant correlations (Anlamlı korelasyonları işaretle) işaretlendiğinde ise korelasyon matrisinde korelasyon katsayısı istatistiksel olarak anlamlı olan değerler ' $*$ ' ile işaretlenecektir. Maddeler arası ilişki değerlerinin 0.20 ile 0.90 arasında bulunması beklenir. Düşük korelasyon katsayısına sahip maddeler diğer maddelerle birlikte hareket etmemekte ve ölçülmek istenen kavramı temsil etmemektedir. Öte yandan, yüksek korelasyon katsayısına sahip (.90 ve üzeri) maddeler ise aynı kavramı ölçen binişik veya aynı maddeler olarak algılanır. Her iki durumda da maddeler ölçeğin yapısına zarar verdiği için madde havuzundan çıkartılmalıdır.

$\mathrm{Bu}$ aşamada maddelerin korelasyon katsayıları Pearson yöntemi ile hesaplanmıştır (Bknz Şekil 14). Örnek çalışmadaki 36 maddenin korelasyon matrisi incelendiğinde .90 üzerinde ilişkiye sahip maddeler bulunmamıştır. Öte yandan, 19 ve 21. maddelerin diğer maddelerin çoğuyla anlamlı ilişki halinde olmadığı ortaya çıkmıştır (Bknz Şekil 14). Bu aşamada bu iki maddenin sorunlu olduğu gözlemlenmiştir. Maddeleri çıkartmak yerine dikkat edilmesi gerekenler listesine eklenerek mercek altına alınmalıdır.

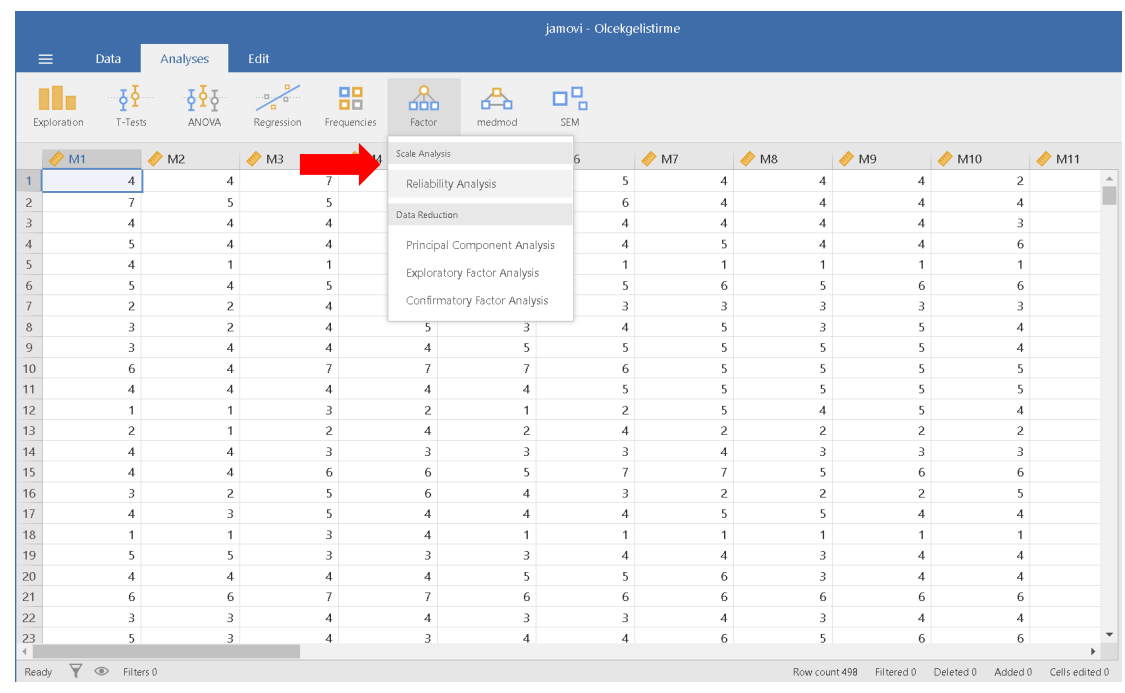

\section{Şekil 15. Faktör Sekmesi Menüsü}

Korelasyon matrisinin incelenmesinin ardından madde analizleri için maddekalan veya madde-toplam korelasyonlarına bakılabilir. Jamovi'de bu katsayılar

Turkish Academic Research Review - Türk Akademik Araştırmalar Dergisi https://dergipark.org.tr/tr/pub/tarr 
Factor (Faktör) sekmesinin altındaki Reliability Analysis (Güvenirlik Analizleri) bölümünde bulunmaktadır (Bknz Şekil 15).

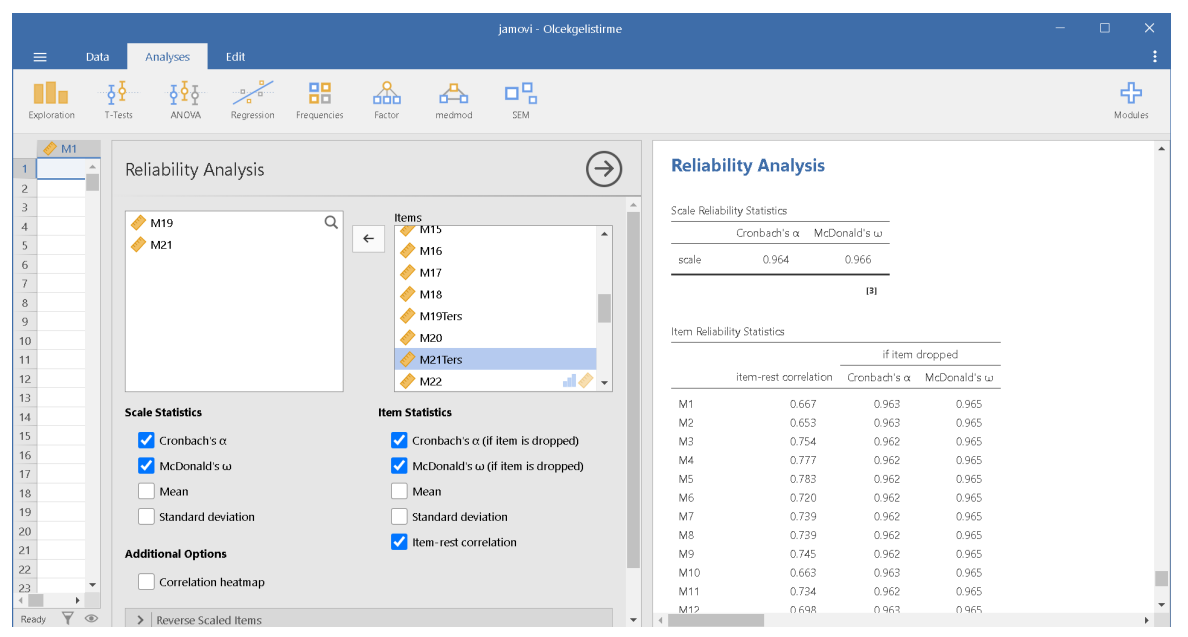

\section{Şekil 16. Güvenirlik Analizi Menüsü}

Reliability Analysis (Güvenirlik Analizleri) için istenen maddeler Items (Maddeler) penceresine atılmalıdır. Item statistics (Madde istatistikleri) bölümünden madde çıkartıldığında Cronbach alfa (Cronbach alpha if item is dropped) veya McDonald's omega (McDonald's omega if item is dropped) katsayıların nasıl değişeceği ve her bir maddenin diğer maddeler ile uyumu (Itemrest correlation) sonuçları elde edilebilir (Bknz Şekil 16).

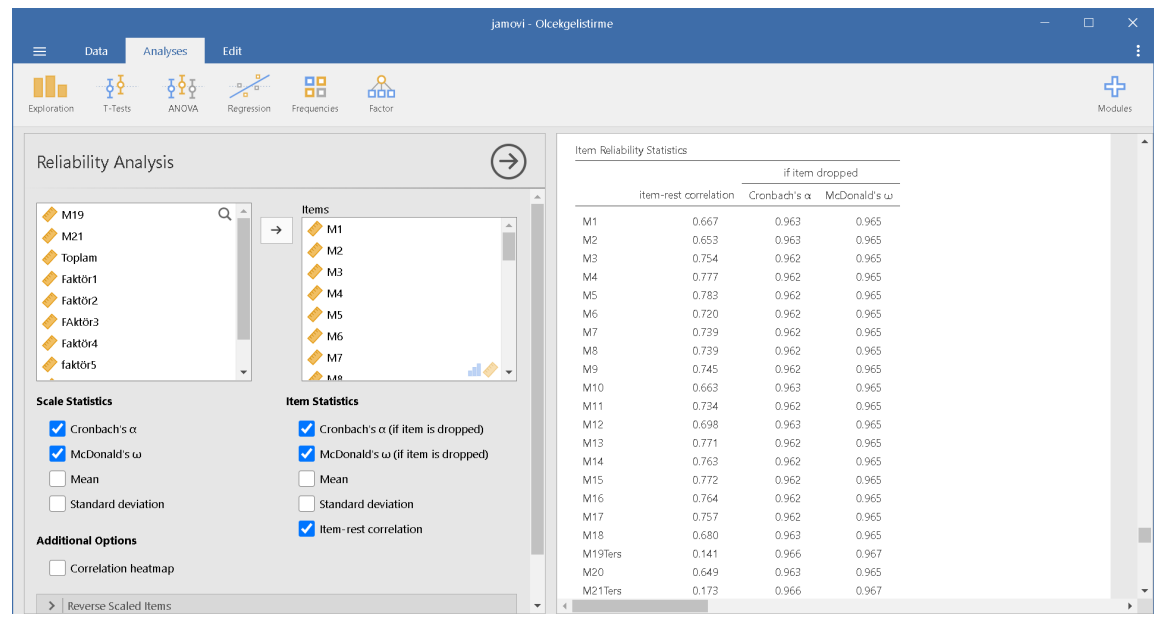




\section{Şekil 17. Madde Analizleri Analiz ve Çıktı Pencereleri Ekran Görüntüsü}

Çıktı penceresindeki Item Reliability Statistics (Madde Güvenirliği İstatistikleri) tablosu her maddeye ait item-rest (madde-kalan) ve if item dropped (madde çıkarıldığında oluşan güvenirlik) değerlerini göstermektedir. Kullanıcı Scale Statistics (Ölçek istatistikleri) ve Item Statistics (Madde Analizleri) bölümlerinden tabloda yer almasını istediği değerleri seçebilmektedir (Bknz Şekil $17)$.

Çalışmadaki maddelerin analizleri incelendiğinde 19 ve 21. maddelerin diğer maddeler ile ilişkisinin düşük olduğu, bu maddeler çıkartıldığında güvenirlik katsayılarının (Hem Cronbach alfa hem de McDonald omega) arttı̆̆ 1 tespit edilmiştir (Bknz Şekil 17). Bu sayede maddelerin ölçekten çıkartılmasına dair kanıtların arttığı söylenebilir.

Son olarak madde analizlerinde ölçeğin tamamından alınan puanlara göre \%27'lik alt ve üst grupların maddelere verdikleri cevaplar karşılaştırılabilir. Elde edilen iki grup(alt ve üst grup) ortalamalarının farkı bağımsız örneklemler t-testi yardımıyla analiz edilir. Hesaplanan $\mathrm{t}$ değeri maddenin ayırt edicilik gücünü gösterdiğinden t-değerinin artması istenilen bir durumdur (Tavşancıl, 2014). Bunu yapabilmek için öncelikle ölçeğin tamamına ait toplam puan hesaplaması yapilmalidir.

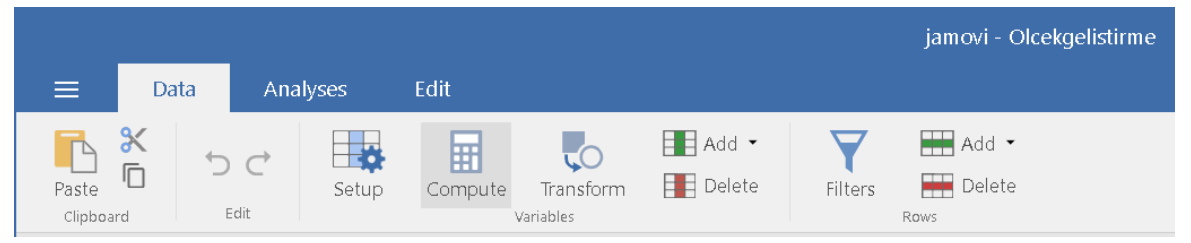

Şekil 18. Veri Sekmesindeki Compute (Hesapla) Bölümü

Toplam puan hesaplayabilmek için Data sekmesindeki Compute bölümü kullanılmalıdır (Bknz. Şekil 18). Veri penceresindeyken maddelerin sonuna gelip bir değişken işaretlendikten sonra Compute komutu çalıştırılabilir. Komut çalıştığında Jamovi anlık olarak yeni bir değişken tanımlanmasına olanak sağlamaktadır.

Turkish Academic Research Review - Türk Akademik Araştırmalar Dergisi https://dergipark.org.tr/tr/pub/tarr 


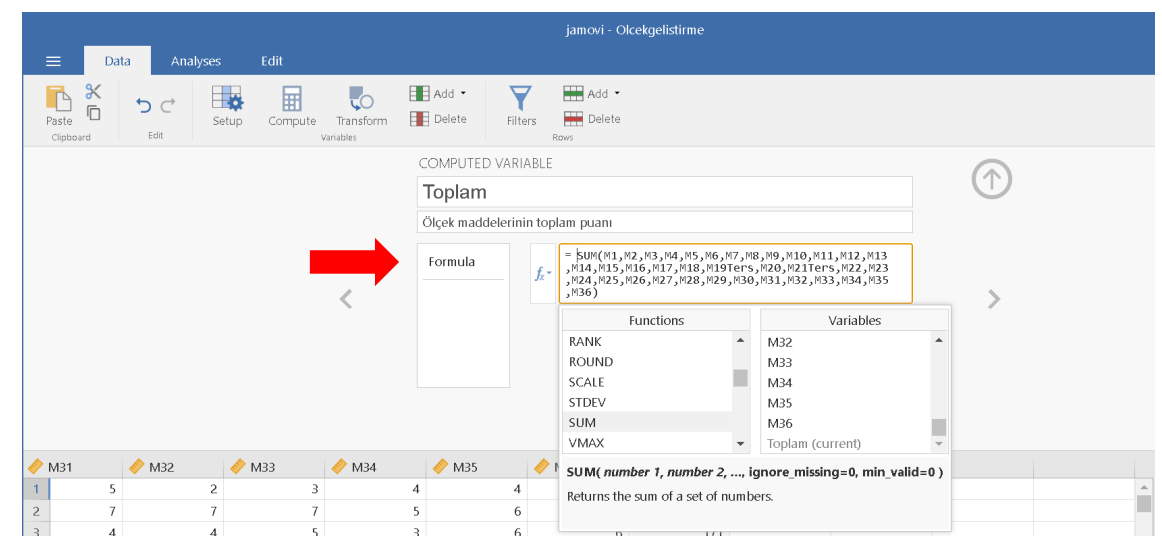

Şekil 19. Veri Sekmesinden Hesaplanan Değiş̧kenin Fonksiyonunu Tanımlama

Açılan yeni değiş̧enin ismi ve açıklaması düzenlendikten sonra bu değişken için gerekli olan formül veya fonksiyon tanımlanmalıdır. Bunun için $\mathbf{f x}$ bölümü tıklanarak hazır fonksiyonlar arasından değişken için uygun olan seçilir. $\mathrm{Bu}$ çalışmada amaç toplam puan oluşturmak olduğu için SUM fonksiyonu kullanılmıştır. SUM fonksiyonuna çift tıklandığında '=' ifadesinden sonra SUM() formülü ortaya çıkmaktadır. Alt bölümde gösterildiği gibi formülün içine konulacak değiş̧kenler virgüller ile ayrılmış olmalıdır. Bu bölümde belirtildiği şekilde ölçekteki tüm maddeler formül parantezlerinin içine yerleştirilmelidir (Bknz Şekil 19).

Toplam puan elde edildikten sonra en yüksek puan alan ve en düşük puan alan katılımcılar belirlenmelidir. Maalesef sütunların büyükten küçüğe veya küçükten büyüğe sıralanması Jamovi programında mevcut değildir. Ancak veriler Excel programına aktarılıp sıralanması kolaylıkla sağlanabilir.

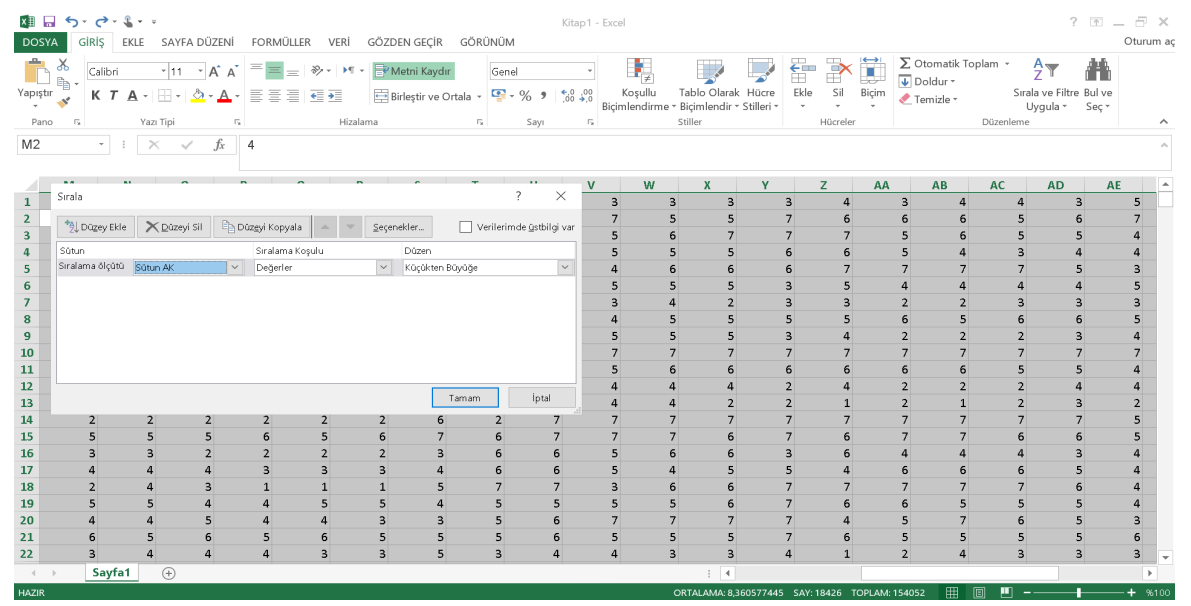

Şekil 20. Excel'de Verilerin Küçükten Büyüğe Sıralanması 
Mevcut çalışmada 498 veri bulunduğundan \%27'lik kısmı 134'e karşılık gelmektedir. Diğer bir ifade ile toplam puandan en düşük puan alan 134 kişi ile en yüksek puan alan 134 kişinin maddelere verdikleri puanlar karşılaştırılmalıdır.

Excel'deki verileri toplam puan üzerinden sıralama yapabilmek için tüm değişkenler seçilip Sırala ve Filtre Uygula sekmesi tıklanır. Özel sıralama seçildikten sonra sıralama ölçütü olarak toplam puan sütunu seçilmelidir. Düzen bölümünden küçükten büyüğe veya büyükten küçüğe seçilerek Tamama tıklandığında tüm veriler toplam puanlara göre küçükten büyüğe sıralanacaktır (Bknz Şekil 20).

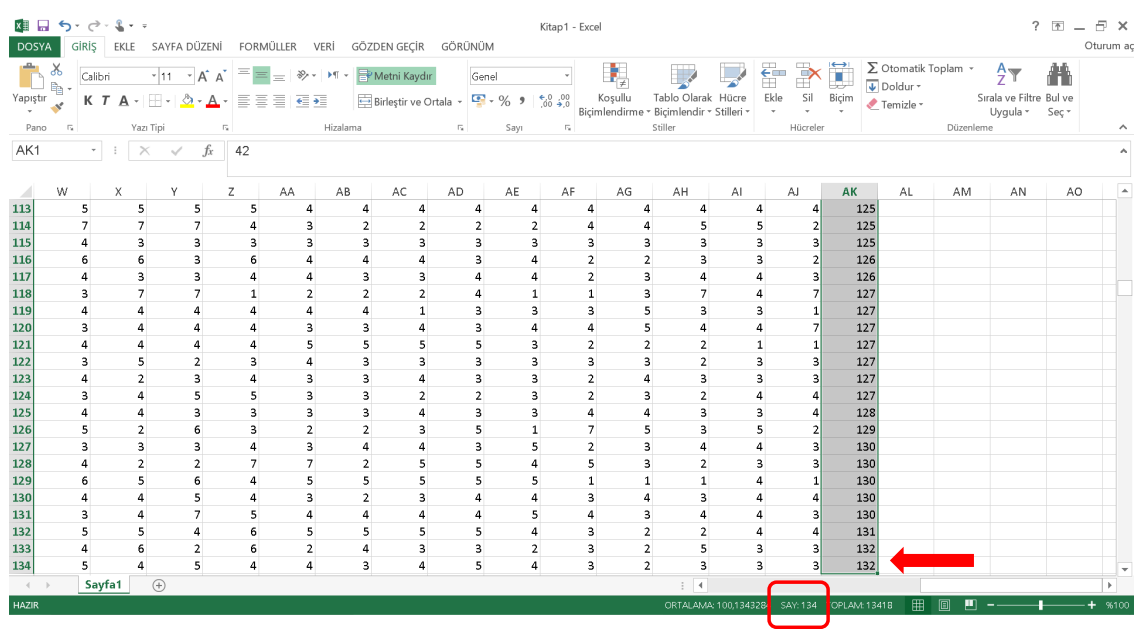

\section{Şekil 21. Toplam Puana Göre Küçükten Büyüğe Sıralanmış Veriler}

Mevcut çalışmada üst grup ve alt gruptan 134'er kişinin verileri mercek altına alınmalıdır. Alt gruptan 134. katılımcının toplam puanına bakıldığında 132 puan aldığı tespit edilmiştir (Bknz Şekil 21).

Turkish Academic Research Review - Türk Akademik Araştırmalar Dergisi https://dergipark.org.tr/tr/pub/tarr 


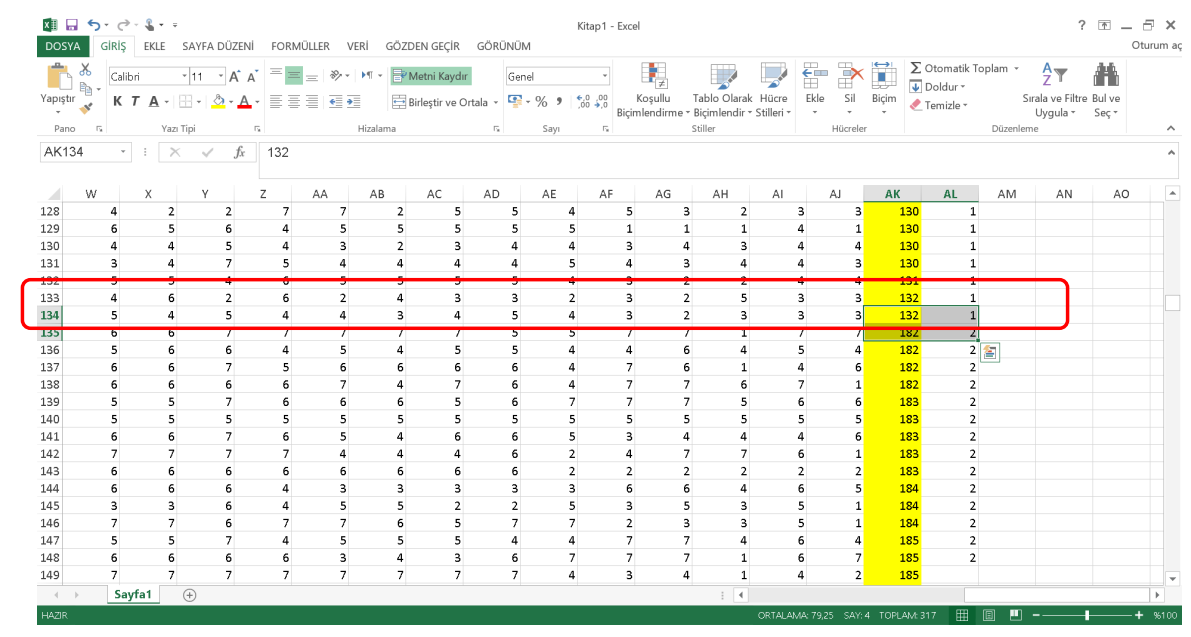

\section{Şekil 22. \%27'lik Alt ve Üst Grup Verilerinin Birleştirilmiş Hali}

Üst gruptan da 134 kişi belirlenip veri setinde işaretlendikten sonra belirlenen iki grup dişında kalan veriler silinir (Bknz Şekil 22). Aradaki veriler silindikten sonra toplam puan sütunun yanına yeni bir değişken (Grup değişkeni) tanımlanır ve bu değişkende Alt grup '1' ve Üst grup '2' ile ifade edilmelidir. Bu şekilde veriler bağımsız örneklemler $\mathrm{t}$ testine hazır hale getirilmiş olur. Mevcut Excel veri dosyası kaydedilip Jamovi programına aktarılır.

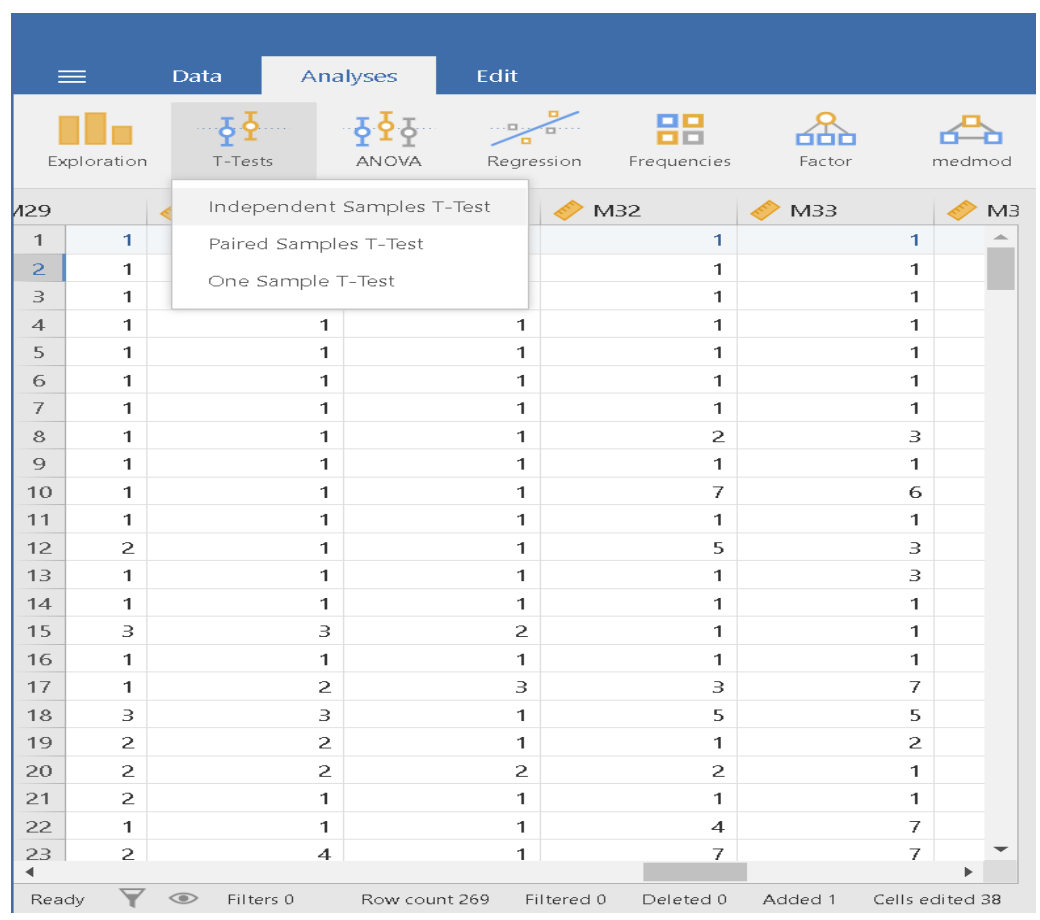




\section{Şekil 23. Analiz Sekmesi Bağımsız Örneklemler T-testi}

Yeni veriler Jamovi programına aktarıldıktan sonra Analyses sekmesindeki Independent Samples t-test (bağımsız gruplar t testi) bölümü tercih edilmelidir (Bknz Şekil 23).

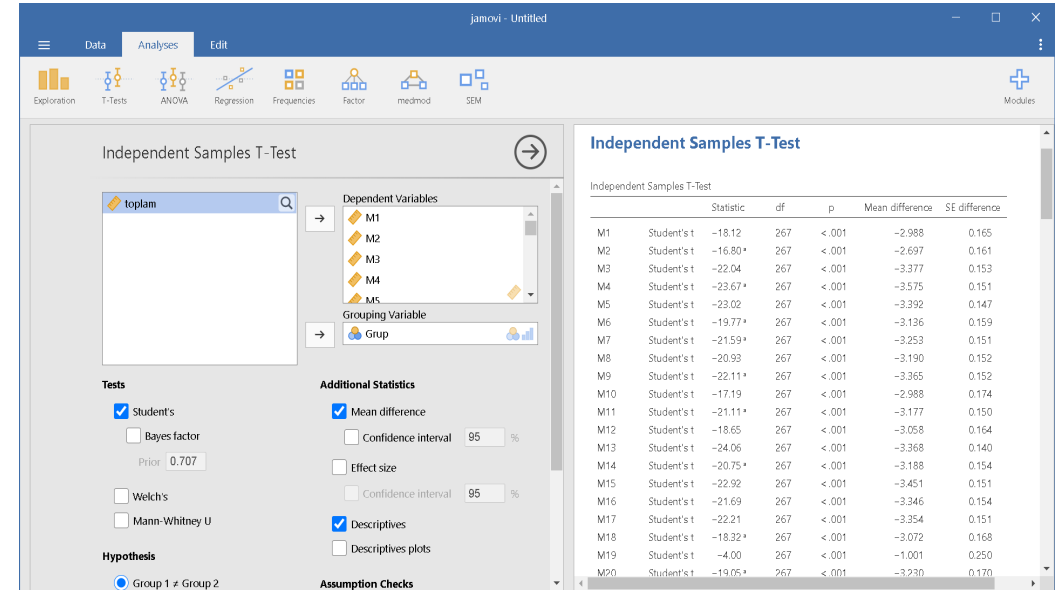

\section{Şekil 24. Bağımsız Örneklemler T-testi Analiz ve Çıktı Penceresi}

Dependent variables penceresine tüm maddeler aktarılır ve Grouping Variable bölümüne ise Grup değişkeni atanmalıdır (Bknz Şekil 24). Çıktı penceresinde ise Independent Samples T-test tablosu oluşmaktadır.

$\mathrm{Bu}$ tabloda bulunan her bir madde için hesaplanmış olan $\mathrm{t}$ istatistikleri (Statistics ve $\boldsymbol{p}$ ) ve ortalama farkları (mean difference) incelenmelidir. Independent Samples t-test tablosundaki p sütunu her maddeye ilişkin hesaplanan t istatistiğinin anlamlılık düzeyini gösterir ve $\mathrm{p}<.05$ olması o madde için gruplar arasında istatistiksel olarak anlamlı farkın olduğunu ifade eder. Mean Difference (ortalama farkı) sütunu ise Alt grup ortalamasından Üst grup ortalamasının farkını göstermektedir. Bu sütundaki değerlerin negatif olması Üst grup ortalamasının alt grup ortalamasından daha yüksek olmasındandır. Örnekte görüldüğü gibi bütün maddelerin ortalamaları alt ve üst gruplar bakımından istatistiksel anlamda farklılık göstermektedir (tüm maddeler için $\mathrm{p}<.05$ ). Ortalama farkları incelendiğinde ise tüm maddelerin negatif değer aldığı belirlenmiştir. Diğer bir ifade ile ikinci grubun yani üst grubun alt gruptan daha yüksek ortalamaya sahip olduğu tespit edilmiştir. Bu bilgiler ışığında tüm maddelerin üst grup ile alt grubu doğru biçimde ayırdığı ifade edilebilir. 
Tüm madde analizi aşamaları dikkate alındığında 19 ve 21 . maddelerde ciddi sorunların olduğu ve ölçekten çıkarılması gerektiği kararı verilebilir. Bu konuda daha fazla kanıt aramak için Açıklayıcı Faktör Analizi sonuçlarına bakmak gerekmektedir.

\subsection{Yapı Geçerliği: Açıklayıcı Faktör Analizi}

Ölçek geliştirme çalışmalarında madde analizlerinin yapılabileceği diğer bir analiz türü Açıklayıcı Faktör Analizi (AFA)'dir. Aynı zamanda bu analiz geçerliliğe dair kanıtlar da sunmaktadır. AFA veri indirgemeye yarayan bir yöntem olup ölçek geliştirirken maddelerin birlikte oluşturdukları faktör yapılarını ortaya koymaktadır (Huck, 2012; Thompson, 2008). Bir kavrama ait ölçek geliştiren araştırmacılar açıklayıcı faktör analizini kullanmak zorundadır (Erkuş, 2012).

Jamovi programında Açıklayıcı Faktör analizi yapmak için Analyses sekmesindeki Factor (Faktör) bölümü kullanılmalıdır (Bknz Şekil 25).

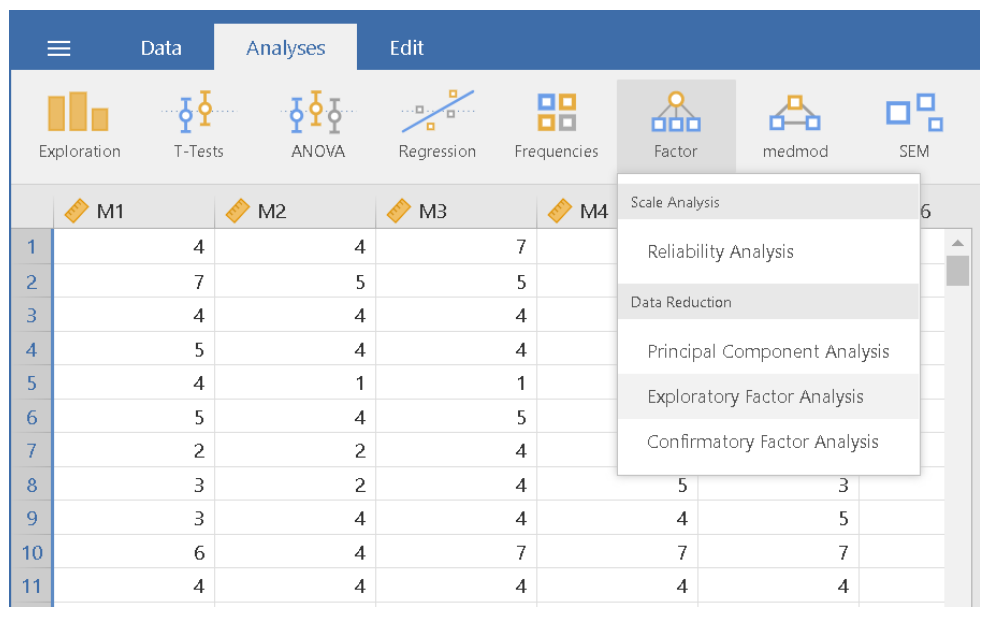

\section{Şekil 25. Faktör Menüsü}

Data Reduction (veri indirgeme) bölümündeki Exploratory Factor Analysis(Açıklayıcı Faktör Analizi) kısmı tıklanarak Açıklayıcı faktör analizine ulaşılabilir. 


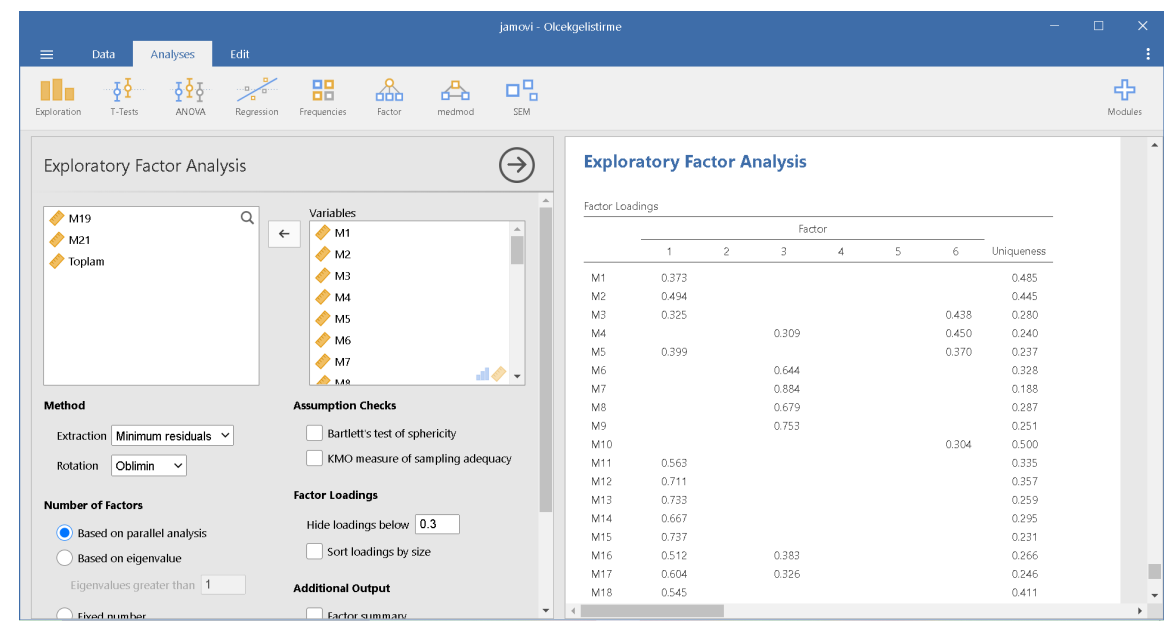

\section{Şekil 26. Açıklayıcı Faktör Analizi Menüsü Analiz ve Çıktı Penceresi}

Faktör yapısını belirlemek istediğimiz tüm maddeler veya değişkenler Variables (değişkenler) kutusuna atılarak analize başlanır (Bknz Şekil 26). Öncelikli olarak, varsayımların test edilmesi gerekmektedir.

Verilerin çok değişkenli normal dağılım gösterip göstermediğini tespit etmek amacıyla varsayımlar bölümü olan Assumption Checks kısmındaki Bartlett's test of sphericity (Bartlett küresellik testi) işaretli olmalıdır. Bartlett testi ölçek maddeleri arasındaki korelasyonların faktörleşmeye uygun olup olmadığını ortaya koymaya yaramaktadır (Karasar, 2010). Bartlett testinin anlamll1ık düzeyinin (p) 0.05'ten küçük olması beklenir (Alpar, 2013; Güriş ve Astar, 2015). Ancak bu test örneklem büyüklüğünden etkilendiği için büyük örneklemlerin bulunduğu analizlerde anlamlı çıkması olasıdır (Tabachnick ve Fidell, 2015). Bunun yanı sıra ölçek geliştirmek için toplanan verilerin yeterliğini belirlemek için Kaiser-MeyerOlkin (KMO) measure of sampling adequecy değeri kontrol edilmelidir. KMO değeri 0 ile 1 arasında değer alabilmekte ve 1'e yakın değerler örneklemin faktör analizi için uygun olduğunu göstermektedir (Alpar, 2013; Field, 2009).

Turkish Academic Research Review - Türk Akademik Araştırmalar Dergisi https://dergipark.org.tr/tr/pub/tarr 


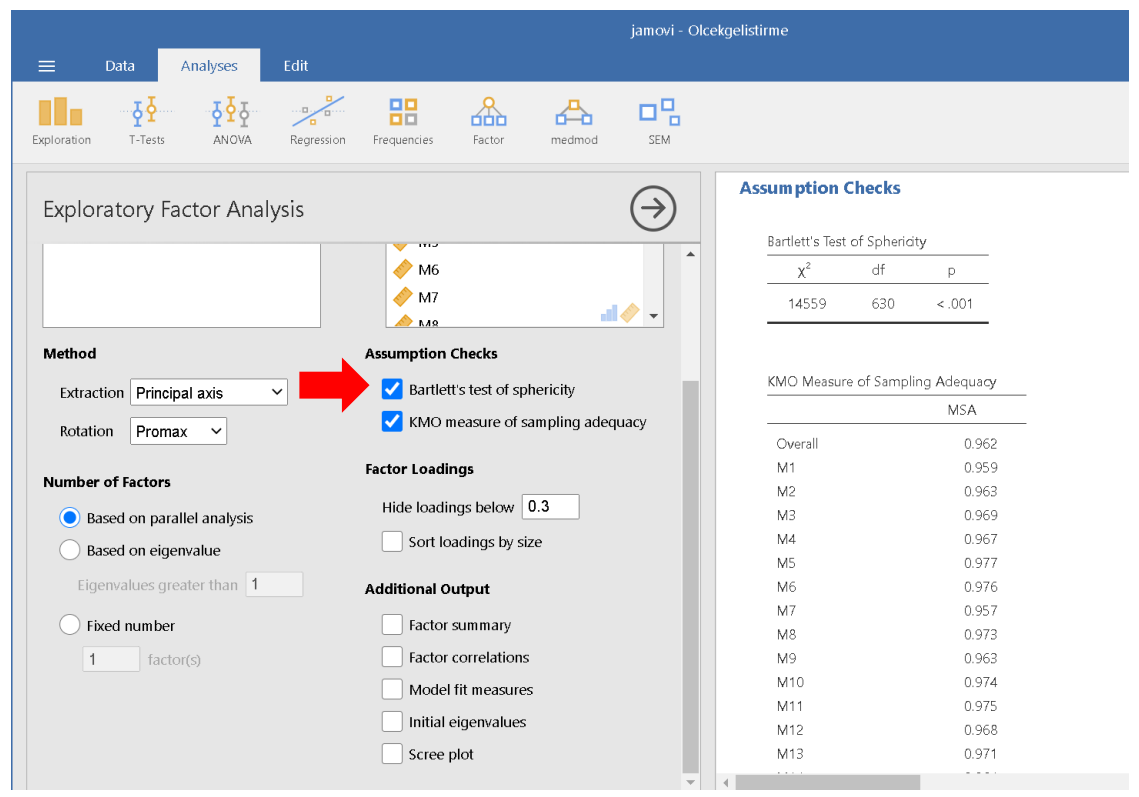

Şekil 27. Açıklayıcı Faktör Analizi Varsayımların Test Edilmesi

Mevcut çalışmanın sonuçlarına bakıldığında Bartlett testi sonuçları istatistiksel olarak anlamlı bulunmuştur (X2: 14559, $\mathrm{p}<.05)$. Bu da değişkenlerin oluşturduğu matrisin birim matristen farklı olduğunu göstermektedir. Diğer bir ifade ile verilerin faktörleşmeye uygun olduğu söylenebilir. Bunun yanı sıra KMO değerlerine göz atılmalı ve ölçeğin tamamı için overall satırındaki değerin .70 ve üzerinde olup olmadığ kontrol edilmelidir (Huck, 2012; Hutcheson ve Sofroniou, 1999; Tabachnick ve Fidell, 2015). Mevcut çalışma sonuçları 962 KMO değeri verdiği için örneklem sayısının yeterli olduğu söylenebilir (Bknz Şekil 27). Bartlett's Test of Sphericity tablosundaki p anlamlılık değeri ve KMO Measures of Sampling Adequecy tablosundaki Overall satırındaki değerin raporlanması tavsiye edilir.

"498 katılımcıdan elde edilen verilerin Açıklayıcı Faktör Analizine uygun olup olmadığ Bartlett test ve Kaiser-Meyer-Olkin (KMO) katsaylları ile incelenmiştir. Bartlett test sonuçlar istatistiksel olarak anlamlı bulunmuştur ( $p<$ .05). KMO katsaylsı (.96) ise kabul edilebilir düzeyin üstündedir (Kalaycl, 2016). Bu sonuçlar değerlendirildiğinde verilerin faktör analizine uygun olduğuna karar verilmiştir." 


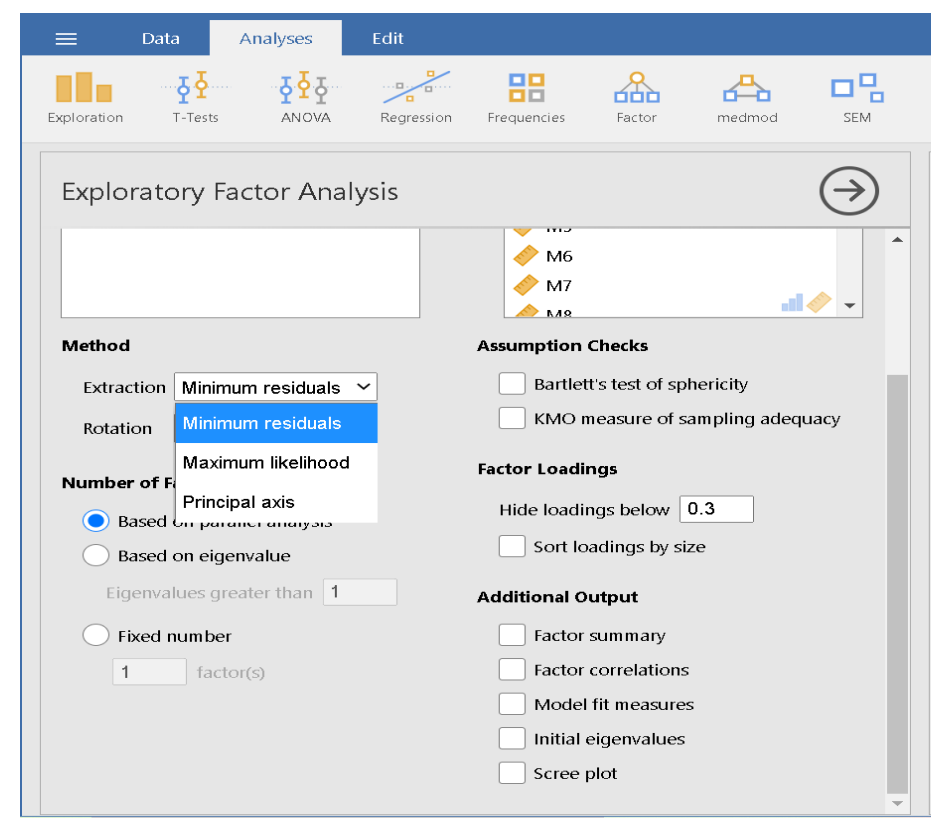

\section{Şekil 28. Faktör Çıkarma Yöntemi Menüsü}

Varsayım kontrollerinden sonra kullanıcı faktör çıkartma yöntemlerine karar verilmelidir. Jamovi programı kullanıcılara faktör çıkarma yöntemi olarak üç yöntem sunmaktadır: minimum residuals (en küçük hatalar), maximum likelihood (en çok olabilirlik) ve principal axis (temel eksen) yöntemleri (Bknz Şekil 28). Her bir yöntemin kendine göre avantajları ve dezavantajları bulunmaktadır. Temel eksen yöntemi literatürde en çok tercih edilen ikinci yöntemdir (Tabachnick ve Fidell, 2015; Thompson, 2008). Ölçek sonuçlarının güvenirlik değerlerinin yüksek olduğu ve maddelerin normal dağılım göstermediği durumlarda tercih edilmesi önerilir (Fabrigar, Wegener, MacCallum ve Strahan, 1999; Thompson, 2008). En çok olabilirlik yöntemi ise faktör analizinin varsayımlarının sağlandığı (verilerin normal dağılım gösterdiği) durumlarda en iyi sonucu veren yöntemlerden biri olarak bilinmektedir (Huck, 2012). Verinin yapısına ve araştırmanın amacına en uygun olan yöntem tercih edilerek faktör döndürme yöntemine kadar verme aşamasına geçilmelidir.

Örnek çalışma kapsamında en sık kullanılan ve normal dağılıma hassas olmayan Principal Axis (Temel eksen) Faktör analizi yöntemi tercih edilmiştir.

Turkish Academic Research Review - Türk Akademik Araştırmalar Dergisi https://dergipark.org.tr/tr/pub/tarr 


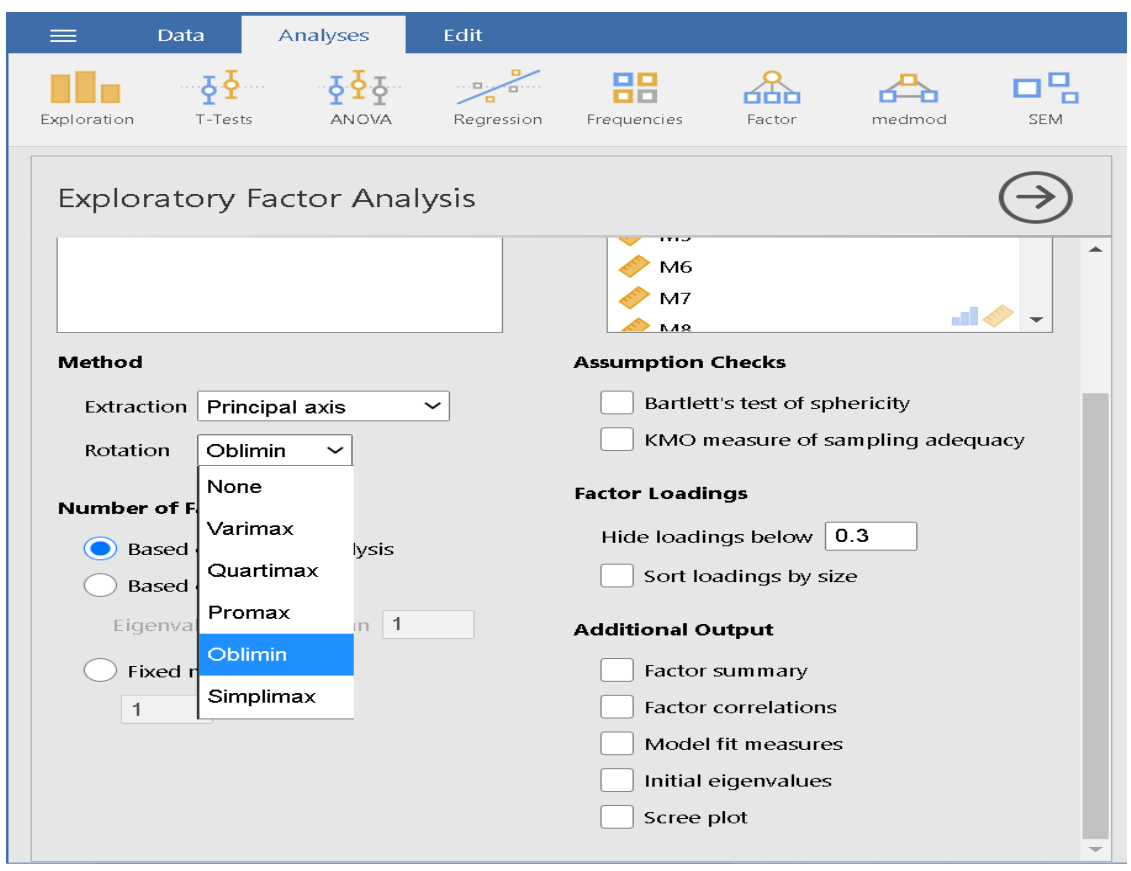

\section{Şekil 29. Faktör Döndürme Yöntemi Menüsü}

Jamovi faktör döndürme yöntemi olarak dik döndürme için varimax ve quartimax yöntemini kullanıcıya sunarken, eğik döndürme yöntemlerinden promax, oblimin (direct oblimin) ve simplimax yöntemlerini ön plana çıkartmıştır (Bknz Şekil 29). Yine araştırma amacına ve verilerin yapısına bağlı olarak dik ve eğik yöntemlerden biri tercih edilmelidir. Ölçek geliştirme çalışmasında ölçülmek istenen kavramın alt boyutları birbiriyle ilişkili ise faktör döndürme yöntemlerinden eğik yöntemler (promax, oblimin veya simplimax) tercih edilmelidir. Büyük örneklemlerin olduğu durumlarda Promax yönteminin kullanılması tavsiye edilmektedir (Hendrickson ve White, 1964; Karasar, 2010). Ancak oblimin yönteminin de iyi bir seçenek olduğu düşünen araştırmacılar bulunmaktadır (Field, 2009). Dik döndürme yöntemlerinde ise faktörlerin birbirleriyle ilişkili olmadığı varsayımı bulunmaktadır (Field, 2009). Bu sebepten ölçek maddelerinden elde edilen faktörlerin ilişkisi yok ise dik döndürme yöntemleri daha doğru sonuçlar ortaya koymaktadır. Dik döndürme yöntemlerinden en sık tercih edileni ise faktörlerin yorumlanmasını kolaylaştıran Varimax yöntemidir (Can, 2018, s. 320; Güriş ve Astar, 2015, s. 417; Huck, 2012, s. 489; Özdamar, 2013, s. 228; Tabachnick ve Fidell, 2015, s. 625; Thompson, 2008). Faktörlerin birbiriyle ilişkilerini tespit etmek için faktör korelasyon matrisinden yararlanılabilir. 
Eğitim alanında çalışılan birçok kavram çok boyutlu yapılardan oluştukları için ve mevcut çalışma için hazırlanan maddelerin birleştiği faktörlerin birbiriyle ilişkili olması beklendiği için faktör döndürme yöntemi olarak Promax yöntemi tercih edilmiştir. Araştırmalarda faktör çıkarma ve döndürme yöntemlerinden bahsedilmesi gerekmektedir.

"Geliştirilen ölçeğin alt boyutları birbiriyle ilişkili olduğu için faktör yükleri Temel Eksen Faktör Analizi ve Promax döndürme yöntemi ile hesaplanmıştır.”

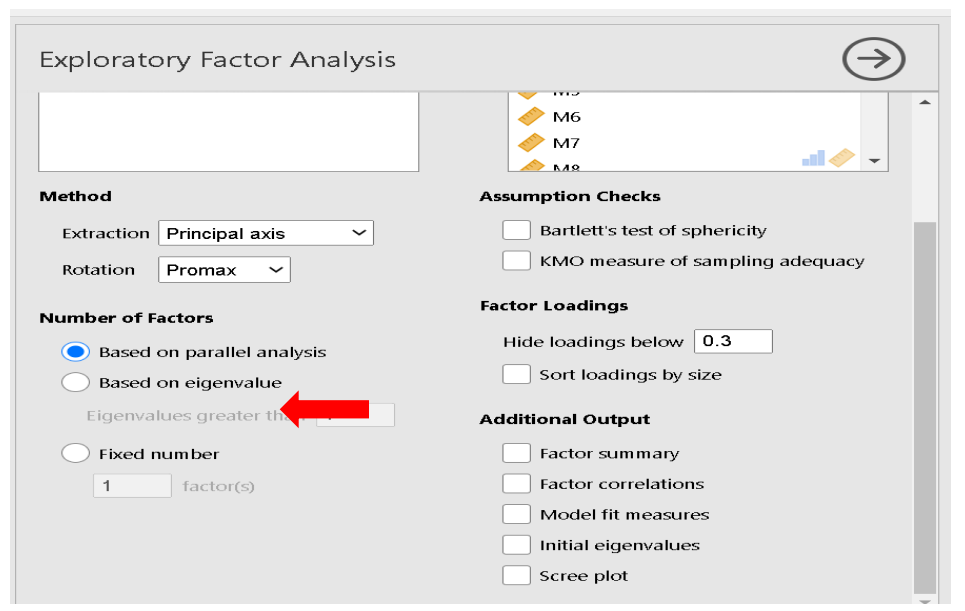

\section{Şekil 30. Açıklayıcı Faktör Analizi Faktör Sayısına Karar Verme}

Faktör analizinin ve dolayısıyla ölçek geliştirme aşamasının en önemli aşamalarından biri faktör sayısına karar vermektir. Bu aşamada uygun olmayan yöntemlerin kullanılması ile gereğinden fazla veya az faktörün belirlenmesi ölçekten elde edilen sonuçların geçerliliğini ciddi boyutta zedeleyebilmektedir. Araştırmacı bu noktada dikkatli davranmalı teorik çerçeveyi ve farklı faktör çıkarma ölçütlerini göz önünde bulundurarak faktör sayısına kadar vermelidir. Faktör sayısına kadar vermede çeşitli ölçütler bulunmaktadır: Kaiser kriteri (Kaiser, 1960, Yamaç grafiği (Cattell, 1966), varyans yüzdesi ölçütü, Minimum Ortalamalar Testi (Velicer, 1976) ve paralel analizi (Horn, 1965). Bu ölçütler arasında en çok tercih edileni ise Kaiser kriteridir. Kaiser'e (1960) göre özdeğeri 1'in üstünde olan tüm faktörler anlamlandırılabilmektedir. Yamaç grafiğinde ise çizginin yatay eksene yakın bir eğim aldığı noktadaki faktör sayısının önemli olduğu söylenmiştir (Cattell, 1966). Ancak bu ölçütler olması gerekenden fazla faktör sayısı gösterdiğinden dolayı eleştiri almış (Cliff, 1998; Hayton, Allen ve Scarpello, 2004; O’Connor, 2000) ve Velicer'in MAP testi (Velicer's Minimum Average Partial Test; Minimum 
Ortalamalar Testi) ve Horn'un Paralel analizi yöntemleri önerilmiştir (Buja \& Eyuboglu, 1992; Hayton ve diğerleri, 2004; Storch, Murphy, Bagner, Johns, Baumeister ve Goodman, 2006; Crawford, Green, Levy, Scott, Svetina, Thompson, 2010; Garrido, Abad, Ponsoda, 2011; Yang \& Xia, 2015).

Faktör sayısına karar verme aşamasına gelindiğinde ise Jamovi Paralel Analiz (Paralel Analysis) yöntemini varsayılan olarak sunmaktadır (Bknz Şekil 30). Ancak özdeğerler (eigenvalue) ve sabit sayı (fixed number) yöntemlerine göre de faktör sayısı belirlenebilmektedir. Ek olarak, Additional output bölümünün altında bulunan Scree plot (Yamaç grafiği) yardımıyla da faktör sayısına karar verilebilir. Eğer kullanıcı faktör sayısına kendisi karar vermek istiyorsa Fixed number (sabit sayı) yöntemini kullanarak istenilen boyutta faktör çıkartılması zorlanabilir. Örnek çalışma için Scree plot ve Eigenvalue yöntemleri olması gerekenden fazla faktör çıkarma eğiliminde olduğu için Paralel analiz yöntemi tercih edilmiştir.

Principal axis faktör çıkartma yöntemi, promax döndürme yöntemi ve paralel analiz ölçütü yardımıyla analiz yapıldığında çalışmadaki veriler altı faktörlü bir yapı ortaya koymaktadır.

$\mathrm{Bu}$ aşamada kullanıcılar Based on eigenvalue ve Scree plot yöntemlerini tıklayarak farklı yöntemlerin çıkardığı sonuçları karşılaştırabilirler ve teorik olarak en makul olan faktör sayısına karar verebilirler.

Uyarı: Bu noktada unutulmamalıdır ki teorik olarak desteklenemeyen hiçbir faktör yapısı tek olarak uygun olsa da kabul edilmemelidir. 


\begin{tabular}{|c|c|c|c|c|c|c|c|}
\hline & \multicolumn{6}{|c|}{ Factor } & \multirow[b]{2}{*}{ Uniqueness } \\
\hline & 1 & 2 & 3 & 4 & 5 & 6 & \\
\hline M1 & 0.609 & & & & & & 0.485 \\
\hline M2 & 0.737 & & & & & & 0.445 \\
\hline M3 & 0.651 & & & & & 0.334 & 0.280 \\
\hline M4 & 0.523 & & & & & 0.362 & 0.240 \\
\hline M5 & 0.725 & & & & & & 0.237 \\
\hline M6 & 0.384 & & & & 0.540 & & 0.328 \\
\hline M7 & & & & & 0.796 & & 0.188 \\
\hline M8 & 0.402 & & & & 0.576 & & 0.287 \\
\hline M9 & & & & & 0.667 & & 0.251 \\
\hline M10 & 0.472 & & & & & & 0.500 \\
\hline M11 & 0.832 & & & & & & 0.335 \\
\hline M12 & 0.882 & & & & & & 0.357 \\
\hline M13 & 0.949 & & & & & & 0.259 \\
\hline M14 & 0.853 & & & & & & 0.295 \\
\hline M15 & 0.975 & & & & & & 0.231 \\
\hline M16 & 0.713 & & & & & & 0.266 \\
\hline M17 & 0.799 & & & & & & 0.246 \\
\hline M18 & 0.697 & & & & & & 0.411 \\
\hline M19Ters & & & & & & 0.544 & 0.724 \\
\hline $\mathrm{M} 20$ & & & & & & & 0.547 \\
\hline M21Ters & & & & & & 0.389 & 0.808 \\
\hline
\end{tabular}

\section{Şekil 31. Faktör Yükleri Tablosu}

Mevcut çalı̧̧mada maddelerin faktörlere ait yükleri Factor Loadings tablosunda görülmektedir. Bu tablonun son sütunundaki Uniqueness değerleri maddenin faktörlerden bağımsız olarak ortaya koyduğu değişimi belirtmektedir. $\mathrm{Bu}$ sütundaki değerlerin düşük olması beklenmektedir. Şekil 31'deki Factor loading (faktör yükleri) tablosu incelendiğinde Madde 19 ve Madde 21'in Uniqueness (Biriciklik değer) değerlerinin çok yüksek olduğu görülmektedir. Daha önce hesaplanan madde analizleri de göz önünde bulundurulduğunda bu 19 ve 21 . maddelerin çıkarılmasına karar verilebilir. Madde 19 ve Madde 21 ölçekten çıkartılarak analiz tekrarlanır. Bu aşamada madde çıkartma işlemlerinin tek tek yapılması tavsiye edilir. Biriciklik değerlerine bakılarak önce 21. madde çıkartılmıştır. 


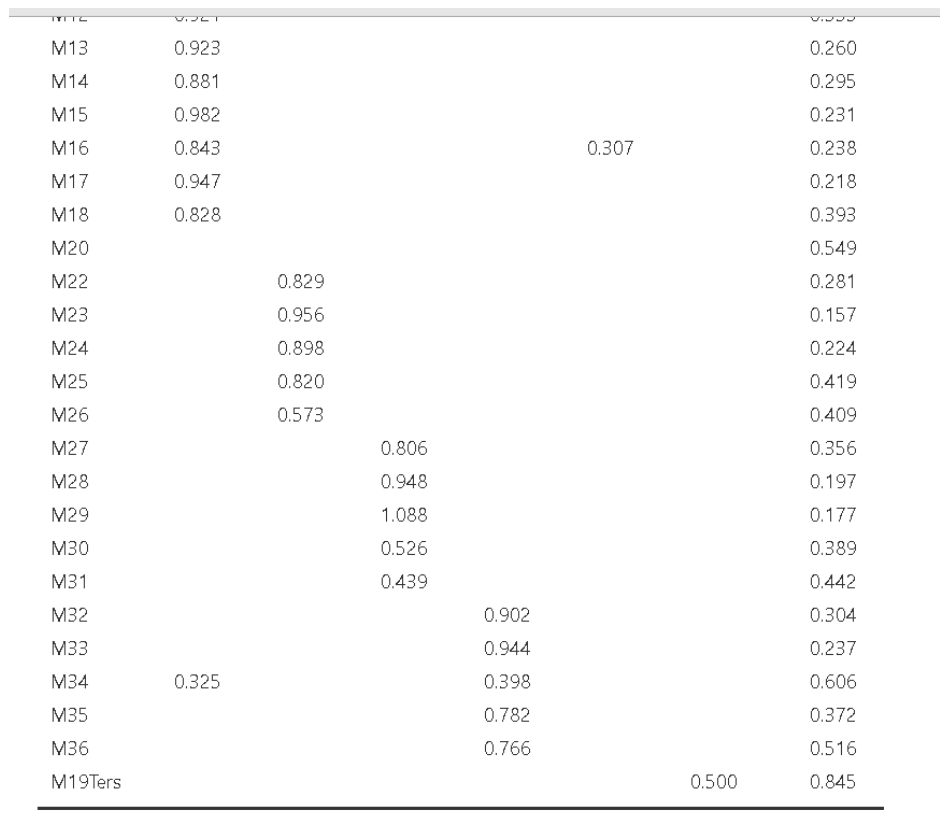

Note. 'Principal axis factoring' extraction method was used in combination with a 'promax'

\section{Şekil 32. Madde 21 Çıkartıldıktan Sonraki Faktör Yükleri}

Şekil 32'deki faktör yükleri tablosu incelendiğinde 21. madde çıkmış hali ile yapılan analizlerde 19. maddenin problemli olmaya devam ettiği belirlenmiştir (Uniqueness .845 'e yükselmiştir). Bu durumda 19 . madde de madde havuzundan çıkartılmalıdır.

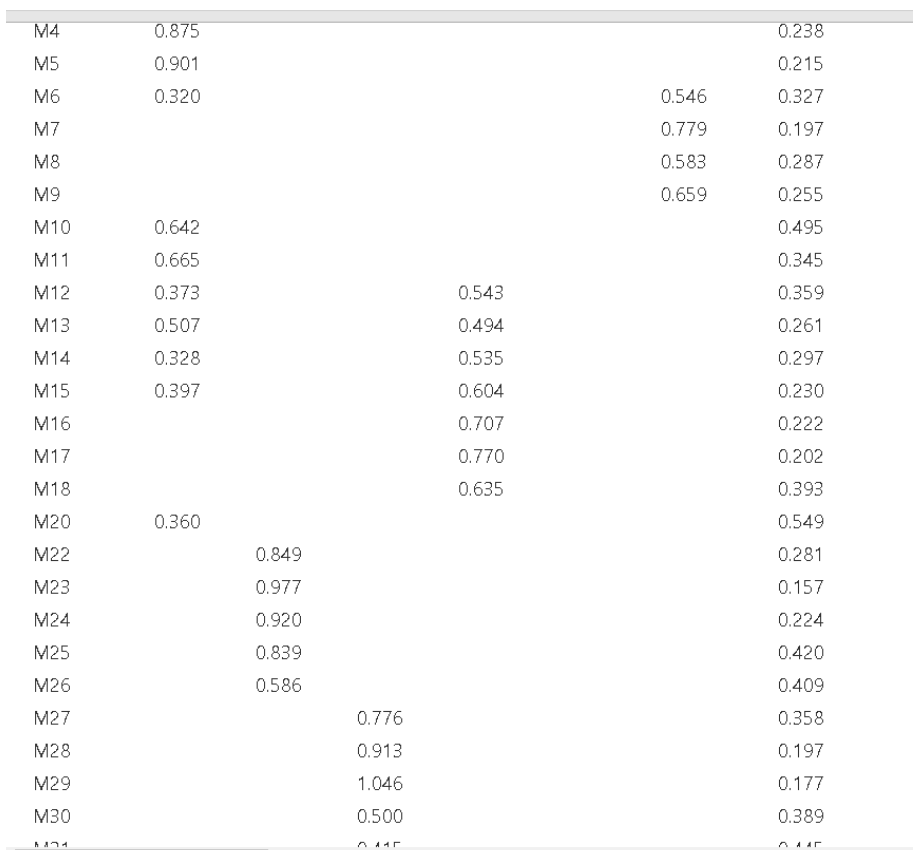




\section{Şekil 33. Madde 19 ve 21 Çıkartıldıktan Sonraki Faktör Yükleri}

Analiz tekrarlandığında tablodaki faktör yükleri ve biriciklik (uniqueness=1communality) değerleri kontrol edilmelidir. Mevcut çalışmada 20. maddenin 1. faktöre çok düşük bir yükle (.360) yüklendiği ve biriciklik değerinin ise diğer maddelere nazaran yüksek olduğu belirlenmiştir (Şekil 33). Madde çıkarma aşamalarının her bir adımında teorik çerçeve ve kapsam geçerliliği gibi konular göz önünde bulundurulmalıdır. Son olarak, 20. maddenin ölçekten çıkartılmasına karar verilir.

Not: Şekil 33'teki tablo incelendiğinde Madde 29'un faktör yükü 1'in üstünde çıktığı belirlenmiştir. Bu durum eğik döndürme yöntemlerinin kullanıldığ zamanlarda ortaya çıkabilmektedir.

\begin{tabular}{|c|c|c|c|c|c|c|}
\hline M10 & 0.613 & & & & & 0.505 \\
\hline M11 & 0.664 & & & & & 0.347 \\
\hline M12 & 0.394 & & & 0.523 & & 0.359 \\
\hline M13 & 0.526 & & & 0.470 & & 0.262 \\
\hline M14 & 0.352 & & & 0.515 & & 0.298 \\
\hline M15 & 0.423 & & & 0.581 & & 0.230 \\
\hline M16 & & & & 0.708 & & 0.220 \\
\hline M17 & & & & 0.773 & & 0.199 \\
\hline M18 & & & & 0.633 & & 0.391 \\
\hline M22 & & 0.835 & & & & 0.281 \\
\hline M23 & & 0.962 & & & & 0.154 \\
\hline M24 & & 0.902 & & & & 0.226 \\
\hline M25 & & 0.828 & & & & 0.418 \\
\hline M26 & & 0.585 & & & & 0.404 \\
\hline M27 & & & 0.772 & & & 0.357 \\
\hline M28 & & & 0.908 & & & 0.197 \\
\hline M29 & & & 1.039 & & & 0.177 \\
\hline M30 & & & 0.503 & & & 0.393 \\
\hline M31 & & & 0.418 & & & 0.448 \\
\hline M32 & & & & & 0.827 & 0.304 \\
\hline M33 & & & & & 0.891 & 0.238 \\
\hline M34 & & & & & 0.383 & 0.605 \\
\hline M35 & & & & & 0.748 & 0.368 \\
\hline M36 & & & & & 0.711 & 0.516 \\
\hline
\end{tabular}

\section{Şekil 34. Madde 19, 20 ve 21 Çıkartıldıktan Sonraki Faktör Yükleri}

19, 20 ve 21. maddelerin çıkartılarak yapılan Açıklayıcı Faktör analizine ait faktör yükleri ve biriciklik (uniqueness) değerleri kontrol edildiğinde madde 34'ün de aykırı davrandığı tespit edilmiştir (Bknz Şekil 34). 34. Maddenin faktör yükü düşük ve biriciklik değeri yüksek bulunmuştur. Teorik çerçeve ve uzman görüşü dikkate alınarak havuzdan çıkartılmasına karar verilmiştir.

Turkish Academic Research Review - Türk Akademik Araştırmalar Dergisi https://dergipark.org.tr/tr/pub/tarr 


\begin{tabular}{|c|c|c|c|c|c|c|c|}
\hline & 1 & 2 & 3 & 4 & 5 & 6 & Uniqueness \\
\hline M1 & 0.737 & & & & & & 0.455 \\
\hline M2 & 0.762 & & & & & & 0.422 \\
\hline M3 & 0.889 & & & & & & 0.279 \\
\hline M4 & 0.826 & & & & & & 0.250 \\
\hline M5 & 0.887 & & & & & & 0.214 \\
\hline M6 & 0.311 & & & & & 0.548 & 0.327 \\
\hline M7 & & & & & & 0.780 & 0.200 \\
\hline M8 & & & & & & 0.588 & 0.286 \\
\hline M9 & & & & & & 0.667 & 0.252 \\
\hline M10 & 0.611 & & & & & & 0.505 \\
\hline M11 & 0.672 & & & & & & 0.349 \\
\hline M12 & 0.408 & & & 0.511 & & & 0.358 \\
\hline M13 & 0.539 & & & 0.456 & & & 0.262 \\
\hline M14 & 0.363 & & & 0.497 & & & 0.297 \\
\hline M15 & 0.434 & & & 0.564 & & & 0.228 \\
\hline M16 & & & & 0.688 & & & 0.219 \\
\hline M17 & & & & 0.747 & & & 0.201 \\
\hline M18 & & & & 0.621 & & & 0.389 \\
\hline M22 & & 0.838 & & & & & 0.281 \\
\hline M23 & & 0.963 & & & & & 0.155 \\
\hline M24 & & 0.908 & & & & & 0.225 \\
\hline M25 & & 0.831 & & & & & 0.418 \\
\hline M26 & & 0.587 & & & & & 0.404 \\
\hline M27 & & & 0.768 & & & & 0.356 \\
\hline
\end{tabular}

\section{Şekil 35. Madde 19, 20, 21 ve 34 Çıkartıldıktan Sonraki Faktör Yükleri}

34. madde çıkartıldıktan sonra elde edilen faktör yükleri tekrar incelemeye alınır. $\mathrm{Bu}$ aşamada birden fazla faktöre eğilim gösteren maddelerin olduğu gözlemlenmektedir (Bknz Şekil 35). Böyle durumlarda faktör yükleri arasındaki farkın .10'un üzerinde olması beklenmektedir (Büyüköztürk, 2015; Güriş ve Astar, 2015). Maddenin farklı faktörlere ait yükleri arasındaki fark .10'un altında olduğu durumlarda maddenin çıkartılması söz konusudur. Mevcut çalışmadaki maddeler teorik çerçeve kapsamında değerlendirilerek 32 maddelik hali ile kalınmasına karar verilmiştir. Böylelikle çalışmadaki ölçeğin 6 faktörlü bir yapıda olduğu kanaatine varılmıştır. Madde havuzundan hangi maddelerin çıkartıldığı ve nihai ölçeğin yapısı açık bir biçimde sunulmalıdır.

"Düşük faktör yüklerine sahip olan 19, 20, 21 ve 34. maddeler madde havuzundan çıkartılmıştır. Paralel analiz ölçütü ile ortaya çıkan 6 faktörlü yapının varyansın \%69'luk kısmını açıladığı ortaya konulmuştur. Geriye kalan maddelerin faktör yükleri .497'nin üzerinde bulunmuştur. Birinci alt boyutun altında 1, 2, 3, 4, 5, 10, 11 ve 13. Maddeler, ikinci alt boyutun altinda 22, 23, 24, 25 ve 26. maddeler, üçüncü boyutun alttnda 27, 28, 29, 30 ve 31. maddeler, dördünü alt boyutun altında 12, 14, 15, 16, 17 ve 18. maddeler, beşinci boyutun altında 32, 33, 35 ve 36. 
maddeler ve son olarak altınc boyutun altında ise 6, 7, 8 ve 9. maddeler toplanmıştır."

Araştırmalarda maddelerin faktör yüklerinin raporlanması önemli bilgiler sunmaktadır. Ölçek madde ve faktörlerine karar verildikten sonra oluşan faktör yükleri Factor Loadings tablosundaki biçimde okuyucuya sunulmalıdır.

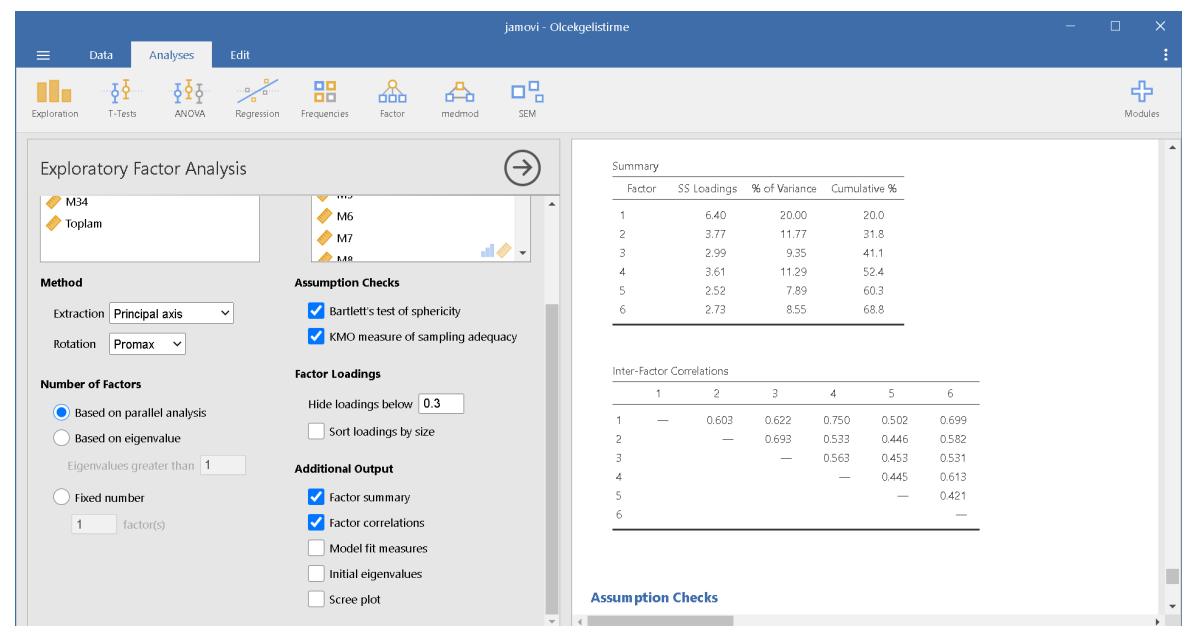

Şekil 36. Faktör Özetleri ve Faktörler Arası Korelasyon Değerleri

Additional output bölümündeki factor summary (faktör özetleri) ve factor correlations (faktör ilişkileri) kısımları işaretlendiğinde Summary (özet) ve InterFactor correlations tabloları çıktı penceresinde yerlerini alır. Summary (özet) tablosunda her bir faktörün katkı sağladığı varyans yüzdesi ve Cumulative (toplamsal) varyans yüzdesi bulunmaktadır. Tablodaki Cumulative \% sütunu ile 6 . faktör satırının kesişimine bakıldığında; altı faktörlü yapının ölçülmek istenen kavramın \%68.8'ini açıkladığı yorumu yapılabilmektedir. Açıklanan varyans oranının \%60 ve üzerinde olması beklenmektedir (Büyüköztürk, 2015). Araştırma raporlarında summary tablosunun son sütunu ile son satırının kesişimindeki değer belirlenen faktörün varyans açıklama yüzdesi olarak okuyucuya sunulmalıdır. Interfactor correlations tablosu da faktörler arasındaki ilişkinin boyutlarını kullanıcıya sunmaktadır (Bknz Şekil 36).

Turkish Academic Research Review - Türk Akademik Araştırmalar Dergisi https://dergipark.org.tr/tr/pub/tarr 


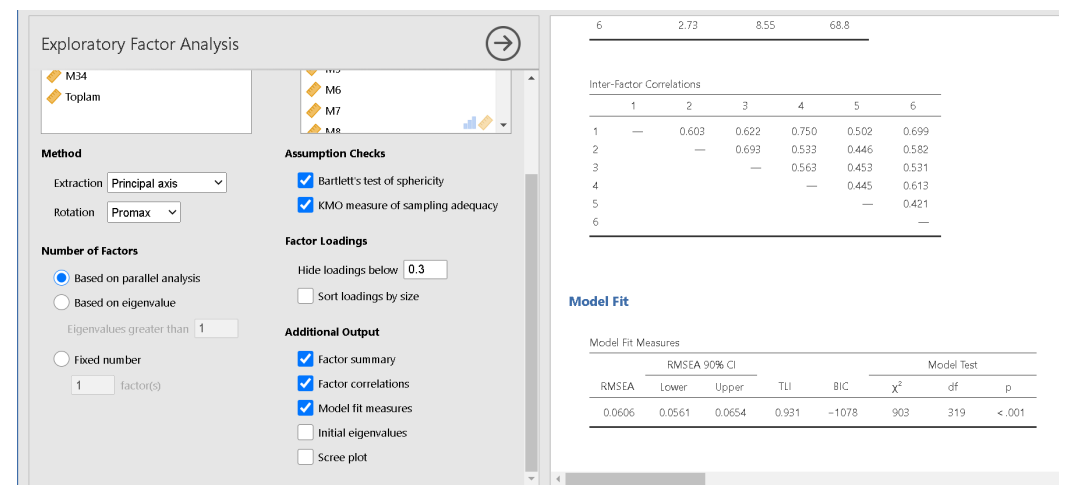

\section{Şekil 37. Model-Veri Uyum İndeksleri}

Additional output bölümündeki model fit measures kısmı işaretlendiğinde Açıklayıcı Faktör Analizi ile belirlenen faktör yapısının Doğrulayıcı Faktör Analizi ile doğrulanıp doğrulanmadığı kontrol edilebilir (Bknz Şekil 37).

Model fit measures tablosundaki RMSEA değerinin .08'in altında olması ve TLI değerinin 90 üzerinde bulunması model-veri uyumunun kabul edilebilir düzeyde olduğunu göstermektedir. Araştırmalarda model-veri uyum indeksleri raporlanırken Model Fit Measures tablosundaki RMSEA, TLI, $\mathbf{X}^{2}(\mathbf{d f})$ ve $p$ değerlerine yer verilmelidir.

\section{Açıklayıcı Faktör Analizi Sonuçlarının Raporlanması}

Ölçek geliştirme çalı̧̧malarında Açıklayıcı faktör analizi sonuçlarının bölümünde;

• Örneklemin özellikleri, yapısı, büyüklüğü ve hangi yöntem ile elde edildiği,

- Toplanan verilerin hangi tipte olduğu (kategorik, sayısal vb.) ve maddelere ait betimsel istatistikler,

- Açıklayıcı faktör analizinin varsayımları olan KMO değeri ve Bartlett testi sonuçları,

- Kullanılan faktör çıkarma ve döndürme yöntemlerinin isimleri (Örnek; temel eksen yöntemi, Promax döndürme yöntemi) ve nedenleri,

- Faktör sayısına karar verirken kullanılan ölçütler (Özdeğererin 1'den büyük olması, Paralel analiz vb.) ve özellikleri, 
- Madde havuzundan çıkartılan maddeler,

- Karar verilen faktör sayısı ve hangi faktör altında hangi maddelerin yer aldı ̆̆1,

- Nihai ölçek maddelerin faktör yükleri ve biriciklik (uniqueness ya da communalities) değerleri (tablo olarak),

- Çıkarılan faktörlerin açıkladıkları varyans oranı,

- Faktörler arasındaki korelasyon katsayıları,

- Ortaya çıkan faktörlerin anlamlı isimlendirilmesi ve bu isme karar verme sebepleri sistematik biçimde raporlanmalıdır.

“Ölçek sonuçlarının geçerliliğine göstermek için Açıklayıcı faktör analizi yapılmıştır. 498 katılımcıdan elde edilen verilerin Açıklayıcı Faktör Analizine uygun olup olmadı̆̆ı Bartlett test ve Kaiser-Meyer-Olkin (KMO) katsayıları ile incelenmiştir. Bartlett test sonuçlarl istatistiksel olarak anlamlı bulunmuştur ( $p<$ .05). KMO katsaylsı (.96) ise kabul edilebilir düzeyin üstündedir (Kalaycl, 2016). Bu sonuçlar değerlendirildiğinde verilerin faktör analizine uygun olduğuna karar verilmiştir. Geliştirilen ölçeğin alt boyutları birbiriyle ilişkili olduğu için faktör yükleri Temel Eksen Faktör Analizi promax döndürme yöntemi ile hesaplanmıştır. Düşük faktör yüklerine sahip olan 19, 20, 21 ve 34. maddeler madde havuzundan çıkartılmıştır. Paralel analiz ölçütü ile ortaya çıkan 6 faktörlü yapının varyansın \%69'luk kısmını açıkladı̆̆ı ortaya konulmuştur. Geriye kalan maddelerin faktör yükleri .497'nin üzerinde bulunmuştur. Birinci alt boyutun altında 1, 2, 3, 4, 5, 10, 11 ve 13. Maddeler, ikinci alt boyutun altında 22, 23, 24, 25 ve 26. maddeler, üçüncü boyutun altında 27, 28, 29, 30 ve 31. maddeler, dördünü alt boyutun altında 12, 14, 15, 16, 17 ve 18. maddeler, beşinci boyutun altında 32, 33, 35 ve 36. maddeler ve son olarak altıncı boyutun altında ise 6,7,8 ve 9. maddeler toplanmıştır. Literatür ve uzman görüşleri çerçevesinde faktörlere uygun isimler verilmiştir. Faktörler arasındaki korelasyon katsayıları, faktör yükleri aşağıdaki tabloda gösterilmiştir. "”

Turkish Academic Research Review - Türk Akademik Araştırmalar Dergisi https://dergipark.org.tr/tr/pub/tarr 
1366 Ölçek Geliştirme ve Güvenirlik Analizleri: Jamovi Uygulaması

Tablo 1. Promax Yöntemi ile Döndürülmüş Açıklayıcı Faktör Analizi Matrisi

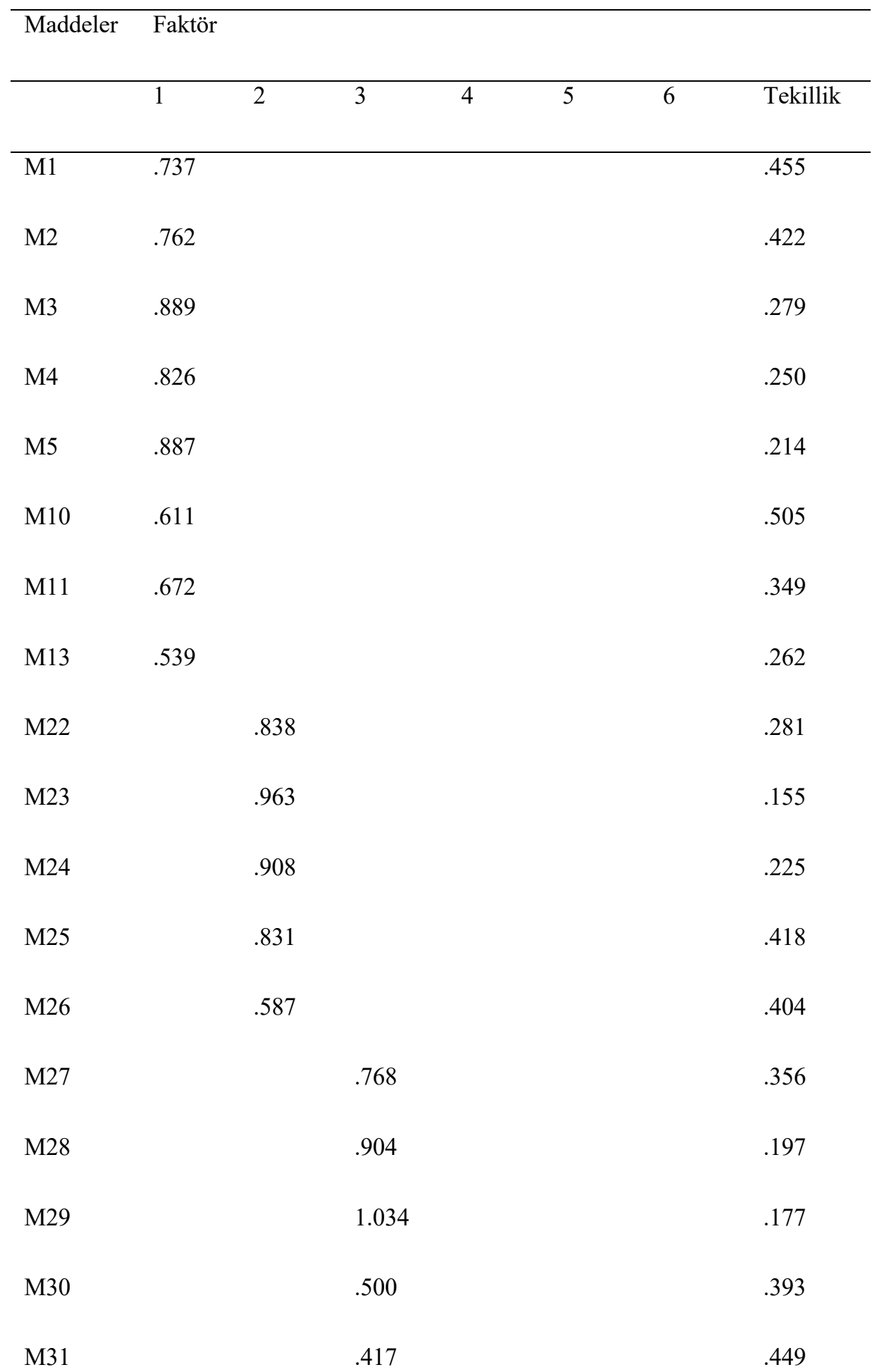




\subsection{Yapı Geçerliği: Doğrulayıcı Faktör Analizi}

Ölçek geliştirme çalışmalarında yapısal model belirlendikten sonra yapının doğrulanması gerekmektedir. Açıklayıcı faktör analizi vasıtasıyla oluşturulan faktörlerin ve maddeler ile olan ilişkilerinin teorik çerçeveyi ne kadar yansıttığını ortaya koymak için Doğrulayıcı Faktör analizinden yararlanılır (Özdamar, 2013). Doğrulayıcı faktör analizinde toplanan verilerin model ile uyumu çeşitli ölçütler ile incelenmelidir. $\mathrm{Bu}$ aşamada verilerin yapısal model ile iyi uyum göstermesi ölçek sonuçlarının geçerliliği konusunda araştırmacıya fikir vermektedir. Ölçek geliştirme çalışmalarında doğrulayıcı faktör analizi yapılabilmesi için farklı bir örneklem grubunun kullanılması tavsiye edilir.

Turkish Academic Research Review - Türk Akademik Araştırmalar Dergisi https://dergipark.org.tr/tr/pub/tarr 
Doğrulayıcı faktör analizinin kararlı parametreler ortaya koyabilmesi için büyük örneklemlere ihtiyaç duymaktadır. Bu konuda farklı görüşler olsa da 300 ve üzeri örneklem büyüklüğü DFA için yeterli kabul edilebilmektedir (Tabachnick ve Fidell, 2015).

Doğrulayıcı faktör analizde model parametlerinin tahmini değerlerinin hesaplanmasında çeşitli yöntemler bulunmaktadır. Tahminleme yöntemlerinden en sık kullanılanı En çok olabilirlik (Maximum Likelihood) yöntemidir. İstatistik yazılımlarında varsayılan parametre tahminleme yöntemi olarak verilen bu yöntem için toplanan verilerin çok değişkenli normal dağıllım göstermesi gerekmektedir. Son olarak, maddelerin birbiriyle doğrusal ilişki göstermesi ancak çoklu birlikte doğrusallık (Multicollinerity) denilen .90 ve üzerinde korelasyona sahip olmaması gerekmektedir (Tabanchnick ve Fidell, 2015). Tüm varsayımlar sağlandığı durumlarda en çok olabilirlik tahminleme yöntemi tercih edilebilir. Normalliğin sağlanamadığ 1 durumlarda ise Robust En çok olabilirlik ve Weighted Leasts Squares yöntemlerinden biri seçilebilmektedir. Jamovi En çok olabilirlik (Maximum likelihood) yöntemi ile parametre katsayılarını hesaplamaktadır. Ancak farklı yöntemlerin kullanılması henüz mümkün değildir.

Doğrulayıcı faktör analizi sonuçları raporlanırken tercih edilen program ve parametre tahminleme yöntemlerinde söz edilmesi gerekmektedir.

"Analiz Jamovi 1.8.4 yazılımı yardımıyla yapılmıştır. Bu analiz için en çok olabilirlik (Maximum likelihood) tahminleme yöntemi tercih edilmişstir."

Mevcut çalışma için açıklayıcı faktör analizinden farklı olan 300 veri kullanılmıştır. Veriler Jamovi programına yüklendikten sonra Analyze Sekmesindeki Factor bölümü tercih edilir. Confirmatory Factor Analysis (Doğrulayıcı Faktör Analizi) seçeneği tıklanmalıdır (Bknz Şekil 38). 


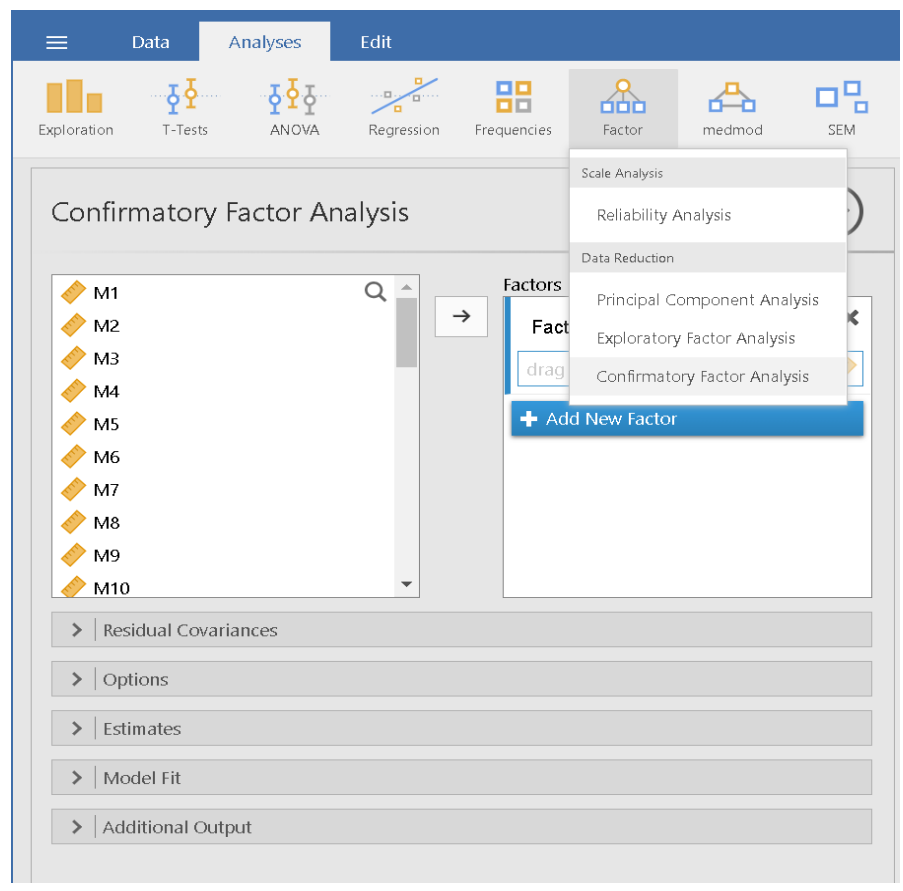

\section{Şekil 38. Faktör (Factor) Menüsü}

Çıkan analiz penceresinde faktörler ve maddeler iki ayrı kutuda bulunmaktadır. Açıklayıcı faktör analizi ile belirlenen faktörler ve faktörlerin altında bulunan maddelerin Factors (Faktörler) kutusunda tanımlanması gerekir.

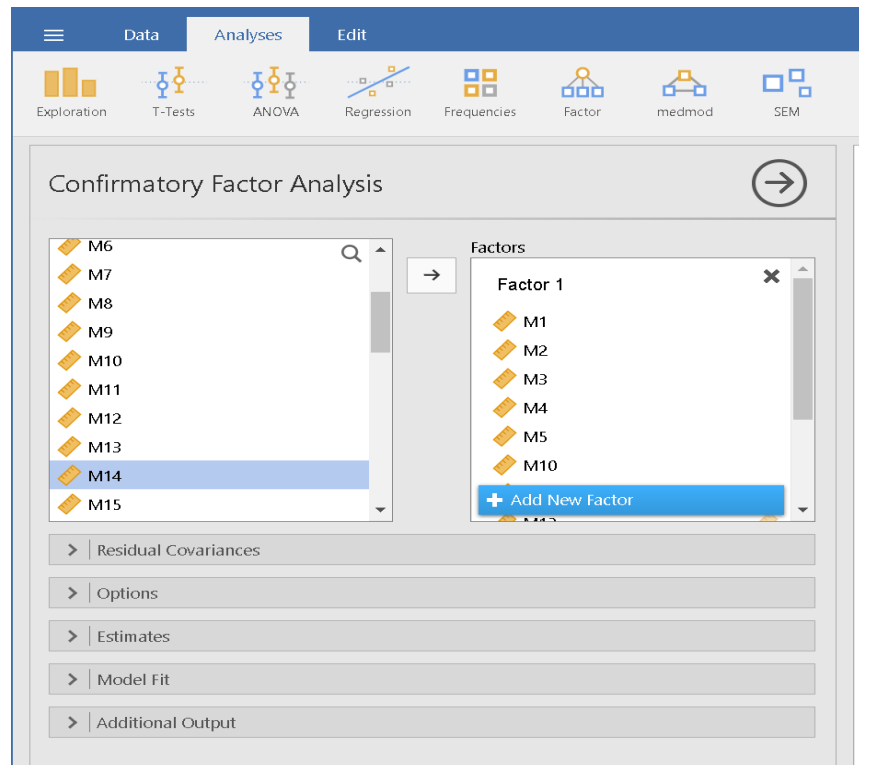

Şekil 39. Doğrulayıcı Faktör Analizi Menüsü

Turkish Academic Research Review - Türk Akademik Araştırmalar Dergisi https://dergipark.org.tr/tr/pub/tarr 
Birinci faktör altında toplanan maddeler Factors kutusuna atıldıktan sonra Add New Factor butonu tıklanarak yeni faktör ve maddeler tanımlanabilir (Bknz Şekil 39).

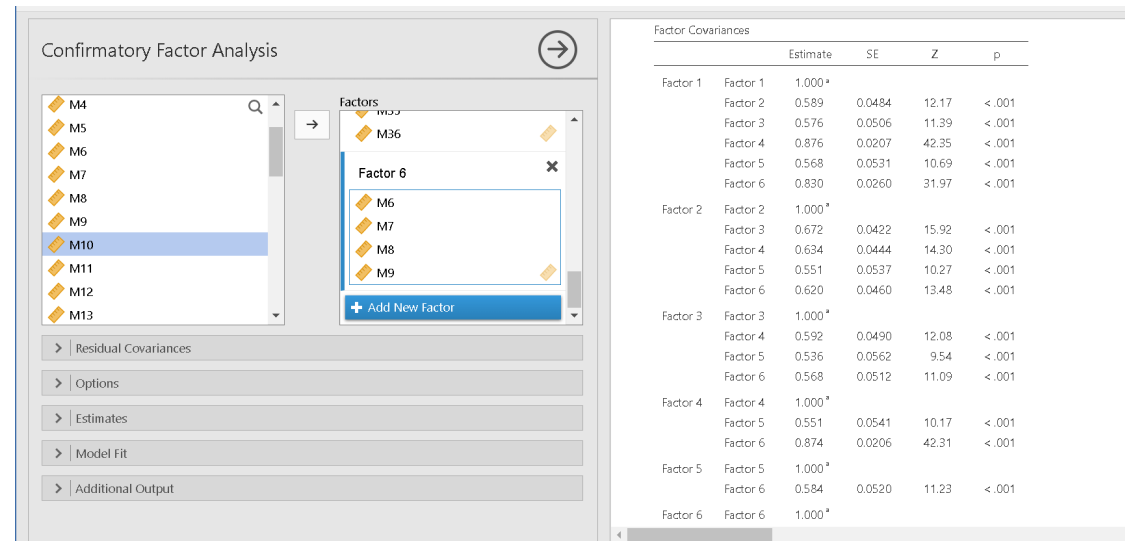

Şekil 40. Doğrulayıcı Faktör Analizi Faktör Kovayransları

Tüm faktörler ve maddeler eşleştirildikten sonra Jamovi anında çıktı penceresinde Factor Covariances (Faktör Kovaryans) ve Model fit (model uyum) tablolarını oluşturmaktadır (Bknz Şekil 40).

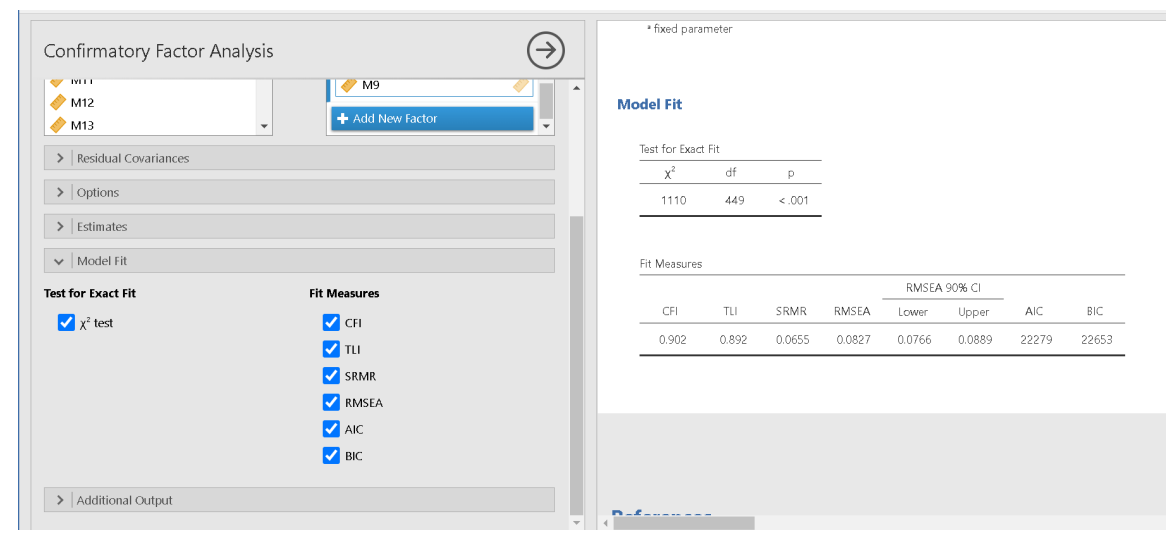

\section{Şekil 41. Model-veri Uyum İndeksleri}

Jamovi, literatürde en çok raporlanan model uyum indekslerinden Chisquare (Ki-kare) testi, CFI, TLI ve RMSEA değerlerini otomatik olarak kullanıcıya sunmaktadır. Ancak analiz penceresindeki Model Fit sekmesi tıklandığında SRMR, AIC ve BIC değerlerinin de tablolara eklenmesine imkan 
sunmaktadır (Bknz Şekil 41). Çıktı penceresindeki model uyum indeksler (Test for exact fit ve Fit measures tabloları) değerlendirilerek varsayılan model kabul edilir.

Mevcut verilerin model ile uyumlarına bakıldığında öncelikle Ki-kare (Chisquare) testinin istatistiksel olarak anlamlı olmaması gerekmektedir. Ancak literatürde bu testin örneklem büyüklüğünden etkilendiği ve büyük örneklemlerde hassas davrandığı kanıtlanmıştır (Bentler ve Bonett, 1980). Alternatif olarak Ki-kare (Chi-square) değerinin serbestlik derecesine (degrees of freedom, df) bölünmesiyle elde edilen değerin 3'ten küçük olması beklenmelidir (Kline, 2011; Sümer, 2000). Mevcut veriler için Ki-kare/sd =1110/449= 2.5 olarak hesaplanmıştır. Ek olarak, CFI ve TLI değerlerinin .90 civarında olduğu ve RMSEA değerinin .08'e yakın olduğu belirlenmiştir (Bknz Şekil 41). Çeşitli kaynaklardan alınan referans değerlere bakıldığında belirlenen uyum indekslerinin kabul edilebilir düzeylerde olduğu tespit edilmiştir (Hu ve Bentler, 1999; Tabachnick ve Fidell, 2015).

Test for exact fit ve Fit measures tablolarında bulunan X2 (df), p, CFI, TLI ve RMSEA değerleri okuyucuya tablo biçiminde sunulmalıdır. İsteğe bağlı olarak SRMR, AIC ve BIC değerleri de raporlanabilmektedir.

"Doğrulayıc faktör analizini değerlendirmek için çeşitli model-veri uyum indekslerinden yararlanılmıştır ve Kikare/sd, RMSEA, CFI ve TLI değerleri hesaplanmıştır. Varsayılan modele ait uyum indeksler aşağıdaki tabloda verilmiştir. Tablodaki referanslar ışığında 32 maddelik altı faktörlü modelin veri ile iyi uyum gösterdiği sonucu çıkartılmıştır. ”,

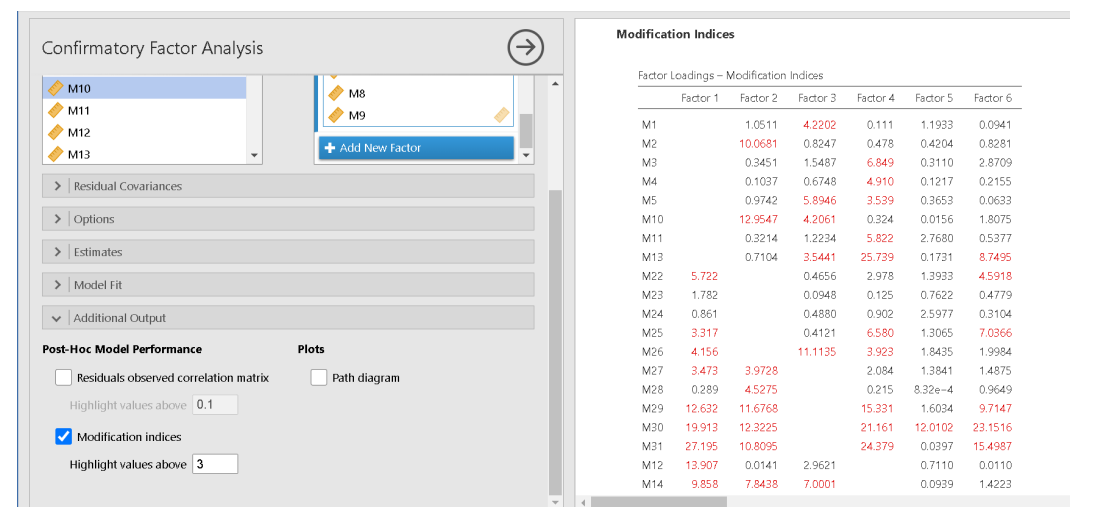

Şekil 42. Doğrulayıcı Faktör Analizi Modifikasyon İndeksleri

Varsayılan modelin tam uyum sağlamadığı ya da modelin geliştirilmek istendiği anlarda Additional Output (Ek çıktılar) sekmesindeki Modification

Turkish Academic Research Review - Türk Akademik Araştırmalar Dergisi https://dergipark.org.tr/tr/pub/tarr 
indices bölümü işaretlenebilir. Çıktı penceresinde iki tablo belirmektedir. İlki maddelerin farklı faktörlere yüklendiğinde oluşan iyileşme (modifikasyon) değerlerini göstermektedir (Factor Loadings - Modification Indices tablosu). İkinci olarak hata kovaryanslarındaki iyileştirme indeksleri sunulmaktadır (Error covariances tablosu). Bu iki tablodaki yüksek iyileştirme indeksleri incelenerek modelde nasıl bir iyileştirme yapılması gerektiğine karar verilebilir. Ancak burada dikkat edilmesi gereken nokta bu iyileştirmeler için teorik olarak kanıt sunulması gerekmektedir. Kanıtsız ve ispatsız yapılan iyileştirmeler veri manipülasyonundan öteye gitmemektedir.

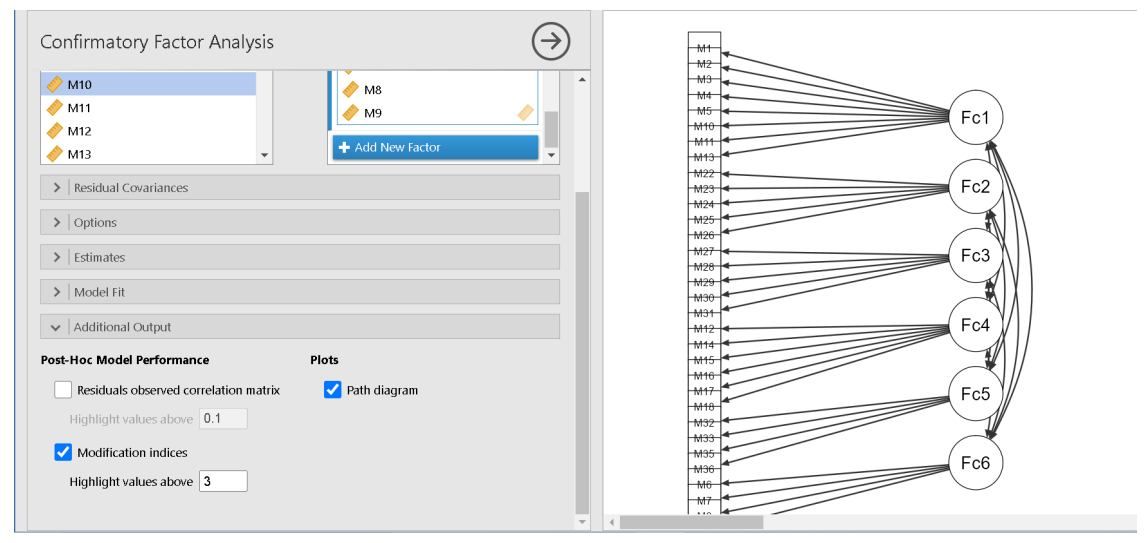

Şekil 43. Doğrulayıcı Faktör Analizi Path Diyagramı

Son olarak, Additional Output sekmesindeki Path Diagram (Yol Grafiği) işaretlendiğinde Doğrulayıcı Faktör analizi ile tanımlanan modelin grafiği çıktı penceresinde yerini alacaktır (Bknz Şekil 43). Araştırmalarda yol grafiğine yer verilmesi ve madde-faktör ilişkilerinin somutlaştırılması tavsiye edilir.

Son yıllarda ölçeğin DFA sonuçlarının iyi uyum göstermesi geçerlilik için yeterli gelmemektedir. Ölçme değişmezliğinin gösterilmesi (measurement invariance) ve ikinci dereceden DFA'nın (Second order CFA) yapılması tavsiye edilmektedir. Araştırmacılar ölçme değişmezliği ile örneklemdeki farklı grupların belirlenen yapıyı doğruladığını ortaya koyması gerekmektedir (Fiala, Bjorck, \& Gorsuch, 2002; Gandek vd., 1998). Bunu test etmenin yollarından biri ise Çok Gruplu Doğrulayıcı Faktör Analizi’dir (Multi Group Confirmatory Factor Analysis). Ölçek geliştiren araştırmacılar kavramın farklı gruplarda aynı yapıyı gösterdiğini ispatlayarak sonuçların geçerliliğine katkıda bulunabilirler. Adından da anlaşılacağı üzere varsayılan modelin farklı gruplar üzerinden doğrulanması amaçlanmaktadır. 
Eğer her grup için Çok Gruplu Doğrulayıcı Faktör Analizi sonuçları benzer çıkarsa o zaman ölçek maddeleri her grup için aynı çalışmaktadır denilebilir.

Ölçek geliştirme çalışmalarında Çok Gruplu Doğrulayıcı Faktör Analizi yaparken grup değişkeni olarak hangi kavramın alınması gerektiği tartışılmaktadır. Genellikle yapılan çalışmalar da cinsiyet, sosyo-ekonomik düzey, ırk, din ve kültür gibi değişkenlerin grup değişkeni olarak tercih edildiği görülmüştür (Jöreskog, Sörbom, Toit \& Toit, 2001). Ancak bu konuda herhangi bir kıstasın olmaması ve grup değişkeni olarak çok sayıda değişken atanabileceği için değişkenin belirlenmesi araştırmacıların öngörüsüne bırakılmıştır.

İkinci Dereceden Doğrulayıcı Faktör Analizi (Second-order Confirmatory Factor Analysis) ise ölçülmek istenen bir üst kavramın var olduğu ve bu üst kavramın alt boyutlarını da dikkate alarak analiz yapılması istendiğinde kullanılabilir.

Jamovi Çok Gruplu ve İkinci Dereceden Doğrulayıcı faktör analizine imkan sağlamamaktadır ancak JASP programını kullanarak bu analizler kolaylıkla uygulanabilmektedir.

\section{Doğrulayıcı Faktör Analizi Sonuçlarının Raporlanması}

Doğrulayıcı Faktör Analizi sonuçlarını raporlarken aşağıdaki noktalara dikkat edilmesi tavsiye edilmektedir.

- Varsayımsal modelin teorik ve ampirik gerekçeleri,

• Örneklemin özellikleri, yapısı, büyüklüğü ve hangi yöntem ile elde edildiği,

- Toplanan verilerin özellikleri (kategorik, sayısal vb.) ve maddelere ait betimsel istatistikler,

- Varsayımların kontrol sonuçları ile kullanılan tahminleme yöntemi,

- Hesaplamaların yapıldığı istatistiksel yazılım ve versiyon numarası,

- Analiz sonucu çıkan model-uyum indeksleri ve bu değerlerin kritik değerleri (kabul edilebilir düzey değerleri),

- Modifikasyon yapıldıysa hangi değişimlerin yapıldığı ve nedenleri,

Turkish Academic Research Review - Türk Akademik Araştırmalar Dergisi https://dergipark.org.tr/tr/pub/tarr 
- Maddelerin faktör yükleri, hata varyansları ile faktörlerin kovaryansları ve onların standart hataları tablo biçimde okuyucuya sunulmalıdır.

“Açıklayıcı faktör analizi ile ortaya konulan 6 faktörlü yapının 300 kişilik farklı bir örneklem üzerinden doğrulanması için doğrulayıcı faktör analizine başvurulmuştur. Analiz Jamovi 1.8.4 yazılımı yardımıyla yapılmıştır. Bu analiz için en çok olabilirlik (Maximum likelihood) tahminleme yöntemi tercih edilmiştir. Doğrulayıcı faktör analizini değerlendirmek için çeşitli model-veri uyum indekslerinden yararlanılmıştır ve Kikare/sd, RMSEA, CFI ve TLI dĕgerleri hesaplanmıştır. Varsayılan modele ait uyum indeksler aşağıdaki tabloda verilmiştir. Tablodaki referanslar ışığında 32 maddelik altı faktörlü modelin veri ile iyi uyum gösterdiği sonucu çıkartılmıştır. DFA modelinin Path diyagramı Şekil 44'de gösterilmiştir. "

Tablo 2. Altı Faktörlü Ölçeğin Model-Veri Uyum İndeksleri

\begin{tabular}{llll}
\hline Uyum indeksleri & $\begin{array}{l}6 \text { faktörlü model } \\
\text { sonuçları }\end{array}$ & $\begin{array}{l}\text { İy } \\
\text { Uyum }\end{array}$ \\
\hline$\chi^{2} 449, p$ & $>.05$ & $<.05$ & $\begin{array}{l}\text { Bentler ve Bonett, 1980; } \\
\text { Çokluk vd., 2014 }\end{array}$ \\
$\chi 2$ Kd & 2.5 & $<4$ & $\begin{array}{l}\text { Kline, 2011; Sümer, 2000 } \\
\text { RMSEA }\end{array}$ \\
& .08 & .08 & $\begin{array}{l}\text { Jöreskog ve Sörbom, 1993; } \\
\text { Özdamar, 2013 }\end{array}$ \\
CFI & .90 & .90 & $\begin{array}{l}\text { Hu ve Bentler, 1999; } \\
\text { Tabachnick ve Fidell, 2015 }\end{array}$ \\
TLI & .89 & .90 & $\begin{array}{l}\text { Hu ve Bentler, 1999; } \\
\text { Tabachnick ve Fidell, 2015 }\end{array}$ \\
\hline
\end{tabular}




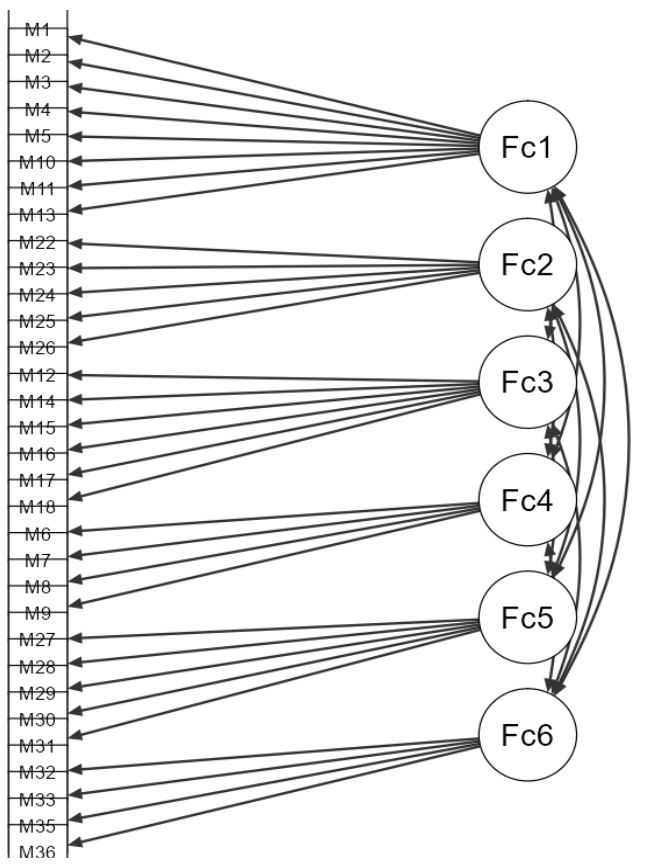

\section{Şekil 44. Altı Faktörlü Yapının Yol Grafiği}

\section{Güvenirlik analizleri}

Ölçekten elde edilen sonuçların yapı geçerliliği kanıtlandıktan sonra güvenirlik katsayılarının okuyucuya sunulması gerekmektedir. Hem alt boyutlara hem de ölçeğin tamamına ait güvenirlik katsayılarının raporlanması tavsiye edilir.

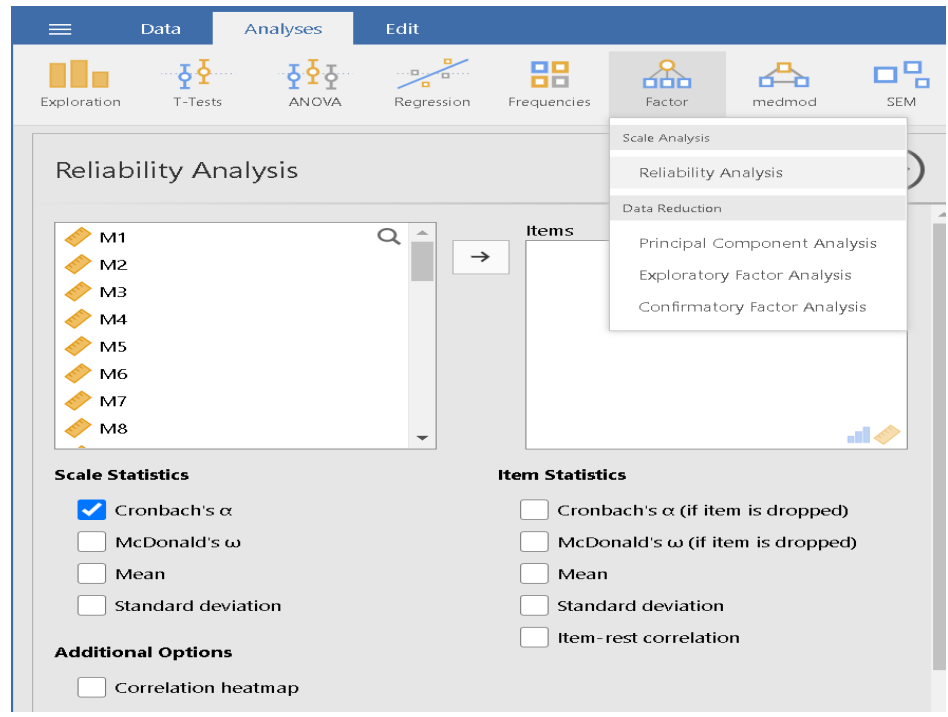

Şekil 45. Güvenirlik Analizi Menüsü

Turkish Academic Research Review - Türk Akademik Araştırmalar Dergisi https://dergipark.org.tr/tr/pub/tarr 
Jamovi programında güvenirlik katsayılarının hesaplanması için Analyses sekmesindeki Factor bölümünün altındaki Reliability Analysis (Güvenirlik Analizleri) seçeneği tercih edilmelidir (Bknz Şekil 45).

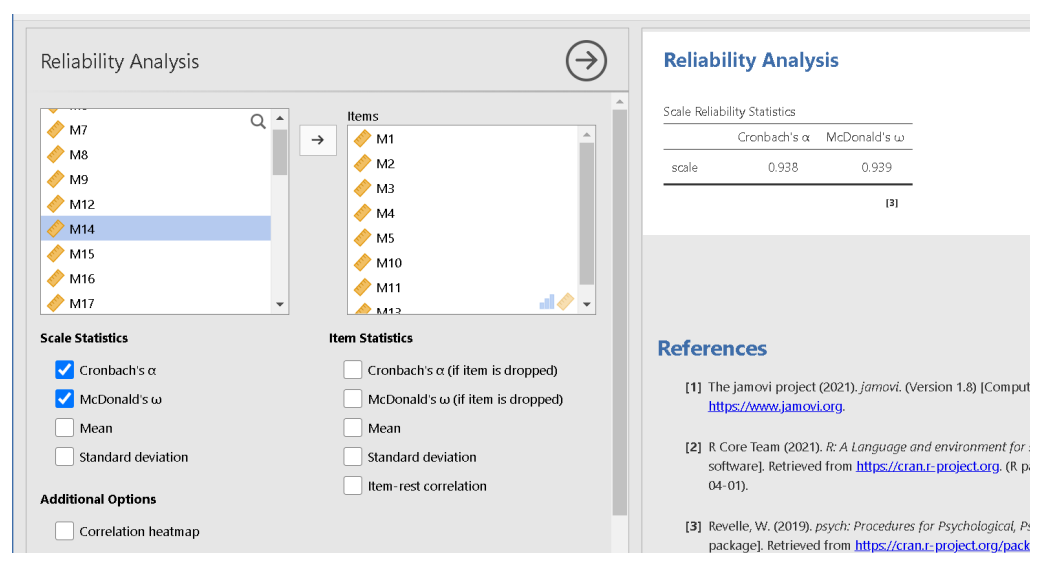

\section{Şekil 46. Güvenirlik Analizi Çıktı Penceresi}

Her bir faktöre ait güvenirlik katsayılarının hesaplanabilmesi için önce maddeler Items kutusuna aktarılmalıdır ve Scale Statistics bölümün altındaki Cronbach alfa ve McDonald's omega seçenekleri işaretlenmelidir. Çıktı penceresinde Scale Reliability Statistics tablosunda seçilen maddelerin oluşturduğu alt boyuta (faktöre) ait güvenirlik analiz sonuçları belirmektedir (Bknz Şekil 46).

Cronbach alfa yöntemi hata terimlerinin ilişkili olmadı̆̆ı, tüm maddelerin aynı faktör yüklerine sahip olduğu ve tek boyutlu bir yapıdan bahsedildiğinde daha doğru sonuçlar ortaya koymaktadır. Bu üç varsayımın sağlanamadığı durumlarda McDonald's omega katsayısı tercih edilmelidir.

Mevcut veriler 1şı̆̆ında Faktör 1'in (1. Alt boyutun) Cronbach alfa katsayısı .938 ve McDonalds omega katsayısı .939 olarak hesaplanmıştır. Elde edilen değerler .70’in üstünde olduğu için kabul edilebilirdir sonucu çıkartılabilir. Diğer faktörler içinde ayrı ayrı güvenirlik katsayıları hesaplanmıştır. Araştırmada güvenirlik katsayıları raporlanırken çıktı penceresindeki Scale Reliability Statistics tablosundaki Cronbach alfa ve McDonald's omega değerleri dikkate alınır.

“Altı faktörlü ölçeğin alt boyutlarına ait güvenirlik katsayıları McDonald Omega yöntemi ile hesaplanmıştır. 6 maddeli birinci alt boyutun güvenirlik katsayısı .939, 5 maddeli ikinci alt boyutun .756, 5 maddeli üçüncü alt boyutun .809, 6 
maddeli dördüncü alt boyutun .885, dört maddeli beşinci alt boyutun .799 ve dört maddeli altıncı alt boyutun 902 olarak bulunmuştur."
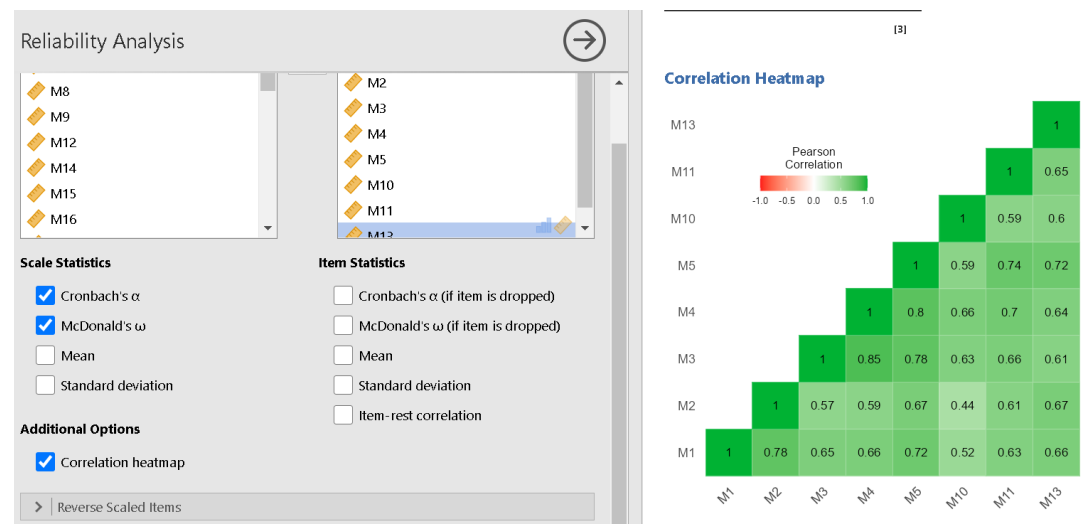

\section{Şekil 47. Korelasyon Isı Haritası}

Additional output sekmesindeki Correlation heatmap(korelasyon 1sı haritası) sekmesi işaretlendiğinde maddelerin birbirleriyle ilişkisini gösteren bir şekil ortaya çıkmaktadır. Böylece maddelerin analizi bu aşamada da yapılabilmektedir.

Her faktör veya alt boyut için bu katsayılar hesaplandıktan sonra ölçeğin tamamı için güvenirlik katsayıları hesaplanmalıdır.

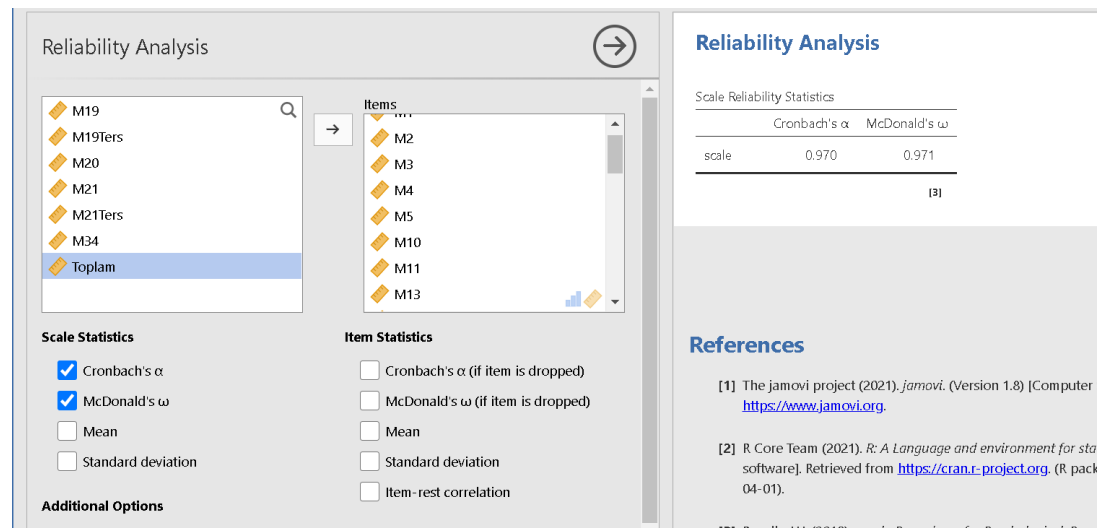

Şekil 48. Ölçeğin Tamamının Güvenirlik Katsayıları

Ölçek maddelerinin tamamı Items kutusuna atıldıktan sonra açıktı penceresinde Scale Reliability Statistics tablosunda ölçeğin tamamına ait güvenirlik 
katsayıları bulunmaktadır (Bknz Şekil 48). Tabloya göre ölçeğin Cronbach alfa katsayısı .970 ve McDonald omega katsayısı .971 'dir. Bu değerlerin yorumlanması aşamasında bazı sakıncalar ortaya çıkmaktadır.

Literatürde yapılan bazı çalışmalar Cronbach alfanın çok boyutlu yapılarda ve varsayımların sağlanmadığı durumlarda iç-tutarlılığı iyi yansıtmadığını ortaya koymuştur (Dunn, Baguley ve Brunsden, 2013). Ek olarak, varsayımların sağlanmadığı durumlarda McDonald's omega katsayısının kullanılması tavsiye edilmiştir. Ancak her iki katsayı da tek boyutluluk varsayımı şartı koştuğu için örnekteki gibi çok faktörlü ölçeklerde tercih edilmemelidir. Geliştirilen ölçek tek boyutlu ise Cronbach veya McDonald katsayıları kullanılabilirken çok boyutlu ölçekler için komposit güvenirlik (composite reliability) katsayıları tercih edilmelidir. Malesef Jamovi Komposite güvenirlik katsayısını hesaplamamaktadır. Alternatif olarak Composite Reliability Calculator websiteleri kullanılabilir. Ek olarak, aşağıdaki formül dikkate alınarak Excel'de hesaplaması yapılabilir.

$$
C R=\frac{\left(\sum \lambda_{i}\right)^{2}}{\left(\sum \lambda_{i}\right)^{2}+\left(\sum \epsilon_{i}\right)}
$$

$$
\epsilon_{i}=1-\lambda_{i}^{2}
$$

CR: Composite Reliability

$\Lambda$ : Faktör yükü

$\epsilon$ : Hata terimi

Hata terimi, faktör yükünün karesinin 1'den çıkarılması olarak yazılabileceği için CR hesaplaması kolaylıkla yapılabilir. 


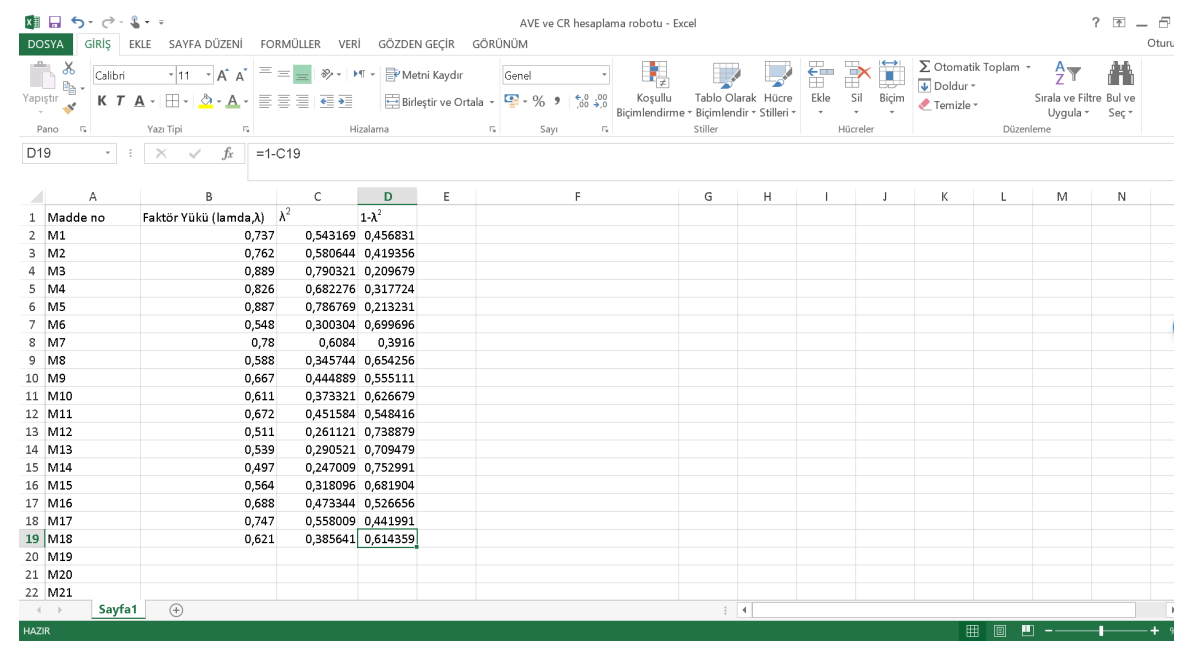

\section{Şekil 49. Excel'de Komposit Güvenirlik Hesaplaması}

Maddeler ve faktör yükleri şekil 49'daki biçimde girildikten sonra faktör yüklerinin karesi 1'den çıkartılarak 1- $\lambda 2$ elde edilir. Her madde için bu hesaplamalar yaptıktan sonra diğer aşamaya geçilir.

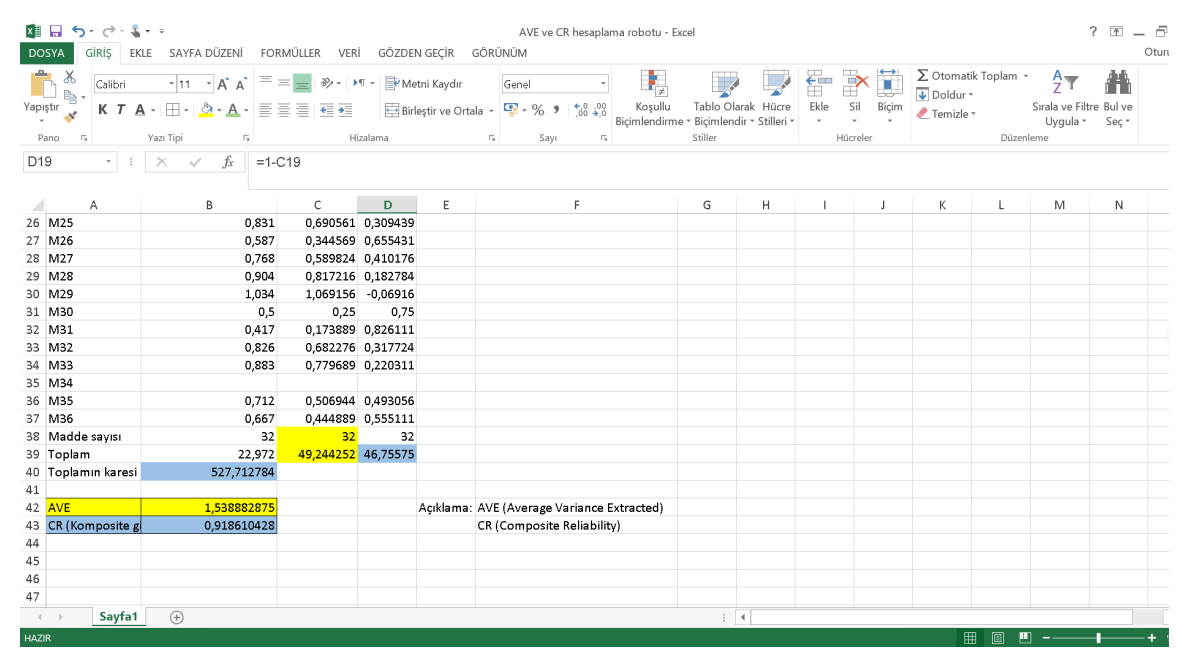

\section{Şekil 50. Komposite Güvenirlik Hesaplama Aşamaları}

Analizde kullanılan madde sayısı, faktör yüklerinin toplamı, faktör yüklerinin karesinin toplamı ve (1- 22$)$ sütunundaki değerlerin toplamı hesaplanır. Sonrasında faktör yüklerinin toplam değerinin karesi alınır. AVE (Çıkarılan varyansın 
ortalaması) için kullanılan değerler sarı ile CR (Komposit Güvenirlik) için kullanılan değerler mavi ile boyanmıştır.

AVE: Toplam(Faktör yüklerinin karesi)/madde sayısı

CR: Toplamın karesi/(Toplamın karesi + Toplam (1-Faktör yükün karesi))

$\mathrm{Bu}$ formüller yardımıyla istenen değerler kolaylıkla hesaplanır. Örnekteki ölçeğin komposite güvenirlik katsayısı 919 olarak hesaplanmıştır (Bknz Şekil 50). Komposit güvenirlik, Cronbach alfaya benzer şekilde .70 ve üzerinde bulunması tavsiye edilmektedir (Nunnally ve Bernstein, 1994). CR ve AVE değerlerini hesaplama robotuna aşağıdaki linkten ulaşabilirsiniz.

https:/drive.google.com/file/d/117YbOzG6gUNm991WQwjoOZOGwrRpJ2P/view? usp=sharing

\section{Güvenirlik Analizi Sonuçlarının Raporlanması}

Ölçek geliştirme çalışmalarında her alt boyut için ayrı ayrı Cronbach alfa veya McDonald omega katsayısının yanı sıra ölçeğin tamamı için de komposite güvenirlik katsayısı raporlanmalıdır. Tercih edilen güvenirlik katsayısı yöntemlerine ait kabul ölçütleri de kaynaklarıyla birlikte okuyucuya sunulmalıdır.

“Altı faktörlü ölçeğin alt boyutlarına ait güvenirlik katsayıları McDonald omega yöntemi ile hesaplanmıştır. 6 maddeli birinci alt boyutun güvenirlik katsayısı .939, 5 maddeli ikinci alt boyutun .756, 5 maddeli üçüncü alt boyutun .809, 6 maddeli dördüncü alt boyutun .885, dört maddeli beşinci alt boyutun 799 ve dört maddeli altıncı alt boyutun 902 olarak bulunmuştur. 33 maddelik ölçeğin tamamına ait komposite güvenirlik katsayıs ise .918 olarak belirlenmiştir. Güvenirlik katsayıları değerlendirildiğinde tüm değgerlerin kabul edilebilir sınırlar (>.70) içinde oldukları sonucuna ulaşılmıştır (Nunally, 1978)." 
Tablo 3. Altı Faktörlü Ölçek Sonuçlarının Güvenirlik Analizleri

\begin{tabular}{|c|c|c|c|c|}
\hline & $\begin{array}{l}\text { Madde } \\
\text { sayısı }\end{array}$ & Ortalama & $\begin{array}{l}\text { Standart } \\
\text { Sapma }\end{array}$ & McDonald Omega \\
\hline $\begin{array}{l}\text { 1. Alt } \\
\text { boyut }\end{array}$ & 8 & 31,0 & 11,5 & 0,939 \\
\hline $\begin{array}{l}\text { 2. Alt } \\
\text { boyut }\end{array}$ & 5 & 25,8 & 7,4 & 0,756 \\
\hline $\begin{array}{l}\text { 3. Alt } \\
\text { boyut }\end{array}$ & 5 & 22,5 & 7,5 & 0,809 \\
\hline $\begin{array}{l}\text { Alt } \\
\text { boyut }\end{array}$ & 6 & 23,9 & 9,0 & 0,885 \\
\hline $\begin{array}{l}\text { 5. Alt } \\
\text { boyut }\end{array}$ & 4 & 17,1 & 6,5 & 0,799 \\
\hline $\begin{array}{l}\text { 6. Alt } \\
\text { boyut }\end{array}$ & 4 & 17,1 & 6,2 & 0,902 \\
\hline $\begin{array}{l}\text { Genel } \\
\text { ölçek }\end{array}$ & 32 & 155 & 42,6 & $\begin{array}{l}0,918 \\
\text { (Komposit } \\
\text { Güvenirlik) }\end{array}$ \\
\hline
\end{tabular}

\section{Sonuç}

Ölçek geliştirme çalışmaları eğitim araştırmalarında önemli bir yere sahiptir. Geliştirilen ölçeklerin standartlara uygun olması gelecek araştırmaların seyrini değiştirecek niteliktedir. Bu sebepten hem ölçek geliştirme aşamalarının istatistiksel analiz kısımlarını net biçimde ortaya koymak hem de son yıllarda popüler olan ücretsiz Jamovi programının kullanımını göstermek amacıyla bu çalışma hazırlanmıştır. Örnek veri seti üzerinden verinin hazırlanması, madde analizleri, açıklayıcı faktör analizi, doğrulayıcı faktör analizi ve güvenirlik katsayıları hesaplanması Jamovi programı yardımıyla okuyucuya sunulmuştur. Bazı eksiklikleri bulunsa da gelişime açık olan bu programın her geçen yıl daha etkili versiyonlarının piyasaya sürüleceği düşünülmektedir 


\section{Kaynakça}

AERA, APA, \& NCME. (1985). Standards for educational psychological tests. Washington: American Psychological Association.

Alpar, R. (2013). Uygulamalı çok değişkenli istatistiksel yöntemler. Ankara: Detay Yayınevi.

Astar, M., \& Güriş, S. (2015). SPSS ile istatistik. Ankara: Der Yayınları.

Bentler, P. M., \& Bonett, D. G. (1980). Significance tests and goodness of fit in the analysis of covariance structures. Psychological Bulletin, 88(3), 588.

Buja, A., \& Eyuboglu, N. (1992). Remarks on parallel analysis. Multivariate Behavioral Research, 27(4), 509-540.

Büyüköztürk, Ş. (2015). Veri analizi el kitabı. Ankara: Pegem.

Cattell, R. B. (1966). The scree test for the number of factors. Multivariate Behavioral Research, 1(2), 245-276.

Cliff, J. E. (1998). Does one size fit all? Exploring the relationship between attitudes towards growth, gender, and business size. Journal of business venturing, 13(6), 523-542.

Crawford, A. V., Green, S. B., Levy, R., Lo, W. J., Scott, L., Svetina, D., \& Thompson, M. S. (2010). Evaluation of parallel analysis methods for determining the number of factors. Educational and Psychological Measurement, 70(6), 885901.

DeVellis, R. F. (2016). Scale development: Theory and applications (Vol. 26). London: Sage publications.

Dunn, T. J., Baguley, T., \& Brunsden, V. (2014). From alpha to omega: A practical solution to the pervasive problem of internal consistency estimation. British Journal of Psychology, 105(3), 399-412.

Erkuş, A. (2007). Ölçek geliştirme ve uyarlama çalışmalarında karşılaşılan sorunlar. Türk Psikoloji Bülteni, 13(40), 17-25.

Fiala, W. E., Bjorck, J. P., \& Gorsuch, R. (2002). The religious support scale: construction, validation, and cross-validation. American Journal of Community Psychology, 30, 761- 786. https://doi.org/10.1023/A:1020264718397

Field, A. (2009). Discovering statistics using SPSS. London: Sage publications.

Gandek, B., Ware J. E., Aaronson N. K., Apolone, G. B., Brazier J. E., et al. (1998). Cross validation of item selection and scoring for the SF-12 health survey in nine countries: results from the iqola project, international quality of life assessment.

Journal of Clinical Epidemiology, 51(11), 1171-1180. https://doi.org/10.1016/S0895-4356(98)00109-7 
Garrido, L. E., Abad, F. J., \& Ponsoda, V. (2011). Performance of Velicer's minimum average partial factor retention method with categorical variables. Educational and Psychological Measurement, 71(3), 551-570.

Hayton, J. C., Allen, D. G., \& Scarpello, V. (2004). Factor retention decisions in exploratory factor analysis: A tutorial on parallel analysis. Organizational Research Methods, 7(2), 191-205.

Horn, J. L. (1965). A rationale and test for the number of factors in factor analysis. Psychometrika, 30(2), 179-185.

Hu, L. T., \& Bentler, P. M. (1999). Cutoff criteria for fit indexes in covariance structure analysis: Conventional criteria versus new alternatives. Structural Equation Modeling: A Multidisciplinary Journal, 6(1), 1-55.

Jöreskog, K. G., \& Sörbom, D. (1993). LISREL 8: Structural equation modeling with the SIMPLIS command language. Scientific Software International.

Jöreskog, K. G., Sörbom, D., Du Toit, S., \& Du Toit, M. (1999). LISREL 8: New statistical features. Chicago: Scientific Software International, 6-7.

Kaiser, H. F. (1960). The application of electronic computers to factor analysis. Educational and psychological measurement, 20(1), 141-151.

Kalayc1, Ş. (2016). SPSS uygulamalı çok değişkenli istatistik teknikleri. Ankara: Asil Yayın Dağıtım.

Kline, R. B. (2011). Principles and practice of structural equation modeling (3. Bask1). New York: Guilford Press.

Muenchen, R. A. (2019). The Popularity of Data Science Software. http://r4stats.com/articles/popularity/ adresinden erişilmiştir.

Nunnally, J. C. (1978). An overview of psychological measurement. Clinical Diagnosis Of Mental Disorders, 97-146.

Nunnally J. C., \& I.H. Bernstein, I. H. (1994). Psychometric theory. New York: McGraw-Hill, New York.

O'connor, B. P. (2000). SPSS and SAS programs for determining the number of components using parallel analysis and Velicer's MAP test. Behavior Research Methods, Instruments, \& Computers, 32(3), 396-402.

Özdamar, K. (2013). Paket programlar ile istatiksel veri analizi: MINITAB 16-IBM SPSS 21. Eskişehir: Nisan Kitabevi.

Storch, E. A., Murphy, T. K., Bagner, D. M., Johns, N. B., Baumeister, A. L., Goodman, W. K., \& Geffken, G. R. (2006). Reliability and validity of the child behavior checklist obsessive-compulsive scale. Journal of Anxiety Disorders, 20(4), $473-485$.

Turkish Academic Research Review - Türk Akademik Araştırmalar Dergisi https://dergipark.org.tr/tr/pub/tarr 
1384 Ölçek Geliştirme ve Güvenirlik Analizleri: Jamovi Uygulaması

Sümer, N. (2000). Yapisal eşitlik modelleri: Temel kavramlar ve örnek uygulamalar. Türk Psikoloji Yazılarl, 3(6),49-74.

Tabachnick, B. G., \& Fidell, L. S. (2015). Using multivariate statistics (Vol. 5). Boston, MA: Pearson.

Tavşancıl, E. (2014). Tutumların ölçülmesi ve SPSS ile veri analizi. Ankara: Nobel Yayıncilik.

Velicer, W. F. (1976). Determining the number of components from the matrix of partial correlations. Psychometrika, 41(3), 321-327.

Yang, Y., \& Xia, Y. (2015). On the number of factors to retain in exploratory factor analysis for ordered categorical data. Behavior Research Methods, 47(3), 756772 . 